\title{
Liver at the nexus of rat postnatal HPA axis maturation and sexual dimorphism
}

\author{
Julia N C Toews ${ }^{\circledR}$, Geoffrey L Hammond and Victor Viau \\ Department of Cellular \& Physiological Sciences, The University of British Columbia, Vancouver, Canada \\ Correspondence should be addressed to J N C Toews: julia.toews@alumni.ubc.ca
}

\begin{abstract}
Normal function of the hypothalamic-pituitary-adrenal (HPA) axis is critical for survival, and its development is choreographed for age-, sex- and context-specific actions. The liver influences HPA ontogeny, integrating diverse endocrine signals that inhibit or activate its development. This review examines how developmental changes in the expression of genes in the liver coordinate postnatal changes in multiple endocrine systems that facilitate the maturation and sexual dimorphism of the rat HPA axis. Specifically, it examines how the ontogeny of testicular androgen production, somatostatin-growth hormone activities, and hypothalamic-pituitary-thyroid axis activity intersect to influence the hepatic gene expression of insulin-like growth factor 1, corticosteroid-binding globulin, thyroxine-binding globulin, 11 $\beta$-hydroxysteroid dehydrogenase type 1 and $5 \alpha$-reductase type 1 . The timing of such molecular changes vary between mammalian species, but they are evolutionarily conserved and are poised to control homeostasis broadly, especially during adversity. Importantly, with the liver as their nexus, these diverse endocrine systems establish the fundamental organization of the HPA axis throughout postnatal development, and thereby ultimately determine the actions of glucocorticoids during adulthood.
\end{abstract}

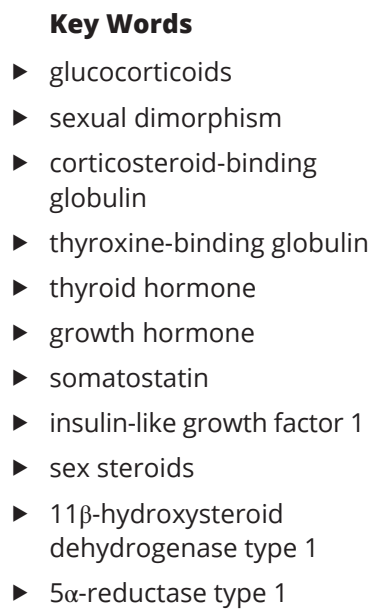

Journal of Endocrinology (2021) 248, R1-R17

\section{Introduction}

As a critical regulator of metabolic homeostasis, the liver senses and integrates hormone signals triggered by alterations in metabolism and/or physiological state in terrestrial vertebrates. Hepatocytes respond to these changes by modifying their intrinsic metabolic activity, as well as the production of plasma proteins that in turn affects nutrient delivery and the activity of multiple endocrine regulatory systems. Many hepatic genes that control these responses are themselves hormonedependent, and are directly or indirectly controlled by factors such as growth hormone (GH), insulin-like growth factor 1 (IGF1), thyroid hormones and steroids; and in particular, the glucocorticoid hormones that govern hepatic gluconeogenesis and glucose availability in the brain and other tissues (Loria et al. 2009).

Glucocorticoid hormones are steroids produced by the adrenal gland that regulate metabolic and homeostatic mechanisms throughout the body (Patel et al. 2014), control inflammation (Kadmiel \& Cidlowski 2013), support reproduction (Whirledge \& Cidlowski 2013) and modulate stress-related behaviors (Myers et al. 2014). Their actions have been studied extensively in relation to normal developmental trajectories in humans and other mammals, and abnormal glucocorticoid exposures during fetal or neonatal life have profound health outcomes in adulthood (Maniam et al. 2014, McGowan \& Matthews 
2018). Normal function of the hypothalamic-pituitaryadrenal (HPA) axis, which controls the plasma levels of glucocorticoids, establishes healthy metabolic function and stress responsivity later in life, and this is influenced by diverse stimuli including maternal care, diet, immune challenge, and stress (Maniam et al. 2014, Buschdorf \& Meaney 2015). Furthermore, differences in the regulation of glucocorticoid action have been linked to sex disparities in inflammatory responses in rats (Duma et al. 2010), as well as the risk for inflammatory diseases, stressrelated disorders and metabolic syndrome in humans (Bourke et al. 2012).

The timing of HPA axis maturation varies across mammals (Pryce 2008), since some species (e.g. primates, sheep, guinea pigs) undergo neuroendocrine maturation in utero while in others (e.g. rats, mice, rabbits) this occurs postnatally (Dobbing \& Sands 1979, Dent et al. 2000). Despite species differences in the ontogeny of HPA axis maturation, the fundamental organization of the HPA axis and the roles of glucocorticoids in the maturation and function of most organ systems are shared across mammalian species, including rodents and humans (Herman et al. 2016), making the rat a valuable model for developmental study. This review discusses the role of the liver in coordinating the activities of several endocrine systems during postnatal development in the rat and how they intersect to promote the maturation of the HPA axis. Importantly, it advances a paradigm for how the liver acts to integrate these endocrine networks that are shared across mammalian species.

\section{HPA axis}

The HPA axis is a neuroendocrine system that operates between the hypothalamus, anterior pituitary, and adrenal glands to regulate plasma glucocorticoid levels. In the hypothalamus, neurosecretory neurons respond to aversive stimuli such as emotional or physical stress, for example, injury, infection, inflammation, or metabolic imbalance, as well as non-aversive stimuli such as circadian cues, by secreting corticotropin-releasing hormone $(\mathrm{CRH})$ and arginine vasopressin. These neuropeptides are transported via the hypophyseal portal veins to the anterior pituitary where they stimulate adrenocorticotrophs to release adrenocorticotropic hormone (ACTH), which in turn stimulates steroidogenesis in the adrenal gland to produce predominantly corticosterone in the rat, and cortisol in humans (Keller-Wood 2015). The HPA axis is self-regulated by glucocorticoids in a negative feedback manner through glucocorticoid-sensitive CRH neurons in the hypothalamus and pro-opiomelanocortin (POMC)-producing adrenocorticotrophs in the pituitary (Gjerstad et al. 2018). Intra-adrenal glucocorticoidmediated negative feedback has also been described (Spiga et al. 2017).

\section{Plasma CBG levels set HPA axis tone}

Prior to exerting their effects in target cells (de Kloet et al. 2019), the activities of glucocorticoids are controlled at two key levels: by binding to CBG in the blood circulation (Hammond 2016), and through enzymatic activation or inactivation in their target cells (Chapman et al. 2013).

Plasma CBG is produced by hepatocytes and is a serine protease inhibitor (SERPIN) family member (Hammond et al. 1987) encoded by SerpinA6 in rodents. Plasma CBG binds glucocorticoids with high affinity, controlling the blood levels of these hormones by reducing their metabolic clearance (Siiteri et al. 1982), thereby serving as the main determinant of glucocorticoid levels (Bolton et al. 2014). However, CBG also regulates the amounts of these hormones that are not bound by plasma proteins and are free to diffuse through the plasma membranes of their target cells (Mendel 1989, Perogamvros et al. 2012). Once inside cells, glucocorticoids activate the intracellular mineralocorticoid receptor (MR) or glucocorticoid receptor (GR) and regulate glucocorticoid-dependent target genes (Reul et al. 2015, Spiga \& Lightman 2015, de Kloet et al. 2019). Importantly, it is widely assumed that it is the 'free' corticosterone fraction rather than 'total' corticosterone, that is responsible for the HPA negative feedback in the brain.

Differences in plasma CBG concentrations between species and sexes are important to understand because they have wider implications on HPA tone (Table 1). In humans, the plasma concentrations of CBG ( $500 \mathrm{nM})$ and cortisol ( $\sim 50-500 \mathrm{nM}$ over the circadian rhythm) are similar between sexes at all ages (Robinson et al. 1985, Russell \& Lightman 2019). During physical trauma in humans, plasma cortisol increases to levels of $\sim 800 \mathrm{nM}$ (Gibbison et al. 2015), which far exceeds the cortisolbinding capacity of $\mathrm{CBG}$, especially since plasma $\mathrm{CBG}$ levels generally decrease under pathological conditions (Hammond 2016). During psychological stress, CBG levels are not expected to change, while salivary cortisol levels as a surrogate measure of free plasma cortisol levels increase 10 -fold, again implying that plasma cortisol levels overshoot CBG levels by a large margin (Deinzer et al. 1997). In mice, plasma CBG ( 200 nM in 
Table 1 Basal and stress levels of CBG and corticosterone in human, mouse and rat.

\begin{tabular}{|c|c|c|c|c|c|c|}
\hline & \multicolumn{6}{|c|}{ Plasma levels ( $\mathrm{nM}$ ) } \\
\hline & \multicolumn{3}{|c|}{ Basal conditions } & \multicolumn{3}{|c|}{ Stress conditions } \\
\hline & Human & Mouse (C57BI/6) & Rat (Wistar) & Human & Mouse (C57BI/6) & Rat (Wistar) \\
\hline Male CBG & $500^{1}$ & $250^{4}$ & $800^{6}$ & $300^{3 *}$ & $250^{5}$ & $800^{6}$ \\
\hline Female CBG & $500^{1}$ & $500^{4}$ & $1,200^{6}$ & $300^{3 *}$ & $500^{5}$ & $1,200^{6}$ \\
\hline Male CORT & $50-500^{2,3}$ & $20-804,5$ & $1-150^{7}$ & $800^{2,3}$ & $250^{4,5}$ & $900^{6}$ \\
\hline $\begin{array}{c}\text { Female } \\
\text { CORT }\end{array}$ & $50-500^{2,3}$ & $40-160^{4,5}$ & $15-350^{7}$ & $800^{2,3}$ & 5004,5 & $1,600^{6}$ \\
\hline
\end{tabular}

*Based on a $\sim 30-50 \%$ reduction in plasma CBG levels observed after cardiac surgery. ${ }^{1}$ Robinson et al. (1985), ${ }^{2}$ Russell \& Lightman (2019), ${ }^{3}$ Gibbison et al. (2015), ${ }^{4}$ Adams et al. (2015), 5Minni et al. (2014), 6 Tinnikov (1999), 7 Seale et al. (2004).

CBG, corticosteroid-binding globulin; CORT, corticosterone.

males, $\sim 400 \mathrm{nM}$ in females) and corticosterone $(\sim 20-80$ $\mathrm{nM}$ in males, $40-160 \mathrm{nM}$ in females, over the circadian rhythm) differ between sexes, but their concentrations approximate those seen in humans, and corticosterone levels also increase to approach or exceed those of CBG under stress conditions (Minni et al. 2014, Adams et al. 2015). As in mice, plasma CBG levels in rats ( $800 \mathrm{nM}$ in males, $\sim 1200 \mathrm{nM}$ in females) are clearly sexually dimorphic (Gala \& Westphal 1965), but they far exceed those of corticosterone $(\sim 1-150 \mathrm{nM}$ in males, $\sim 15-350$ $\mathrm{nM}$ in females, over circadian rhythm) in the circulation (Seale et al. 2004). Therefore, substantial increases in adrenal corticosterone output are required during stress (reaching $~ 900 \mathrm{nM}$ in males, $\sim 1600 \mathrm{nM}$ in females) to increase free corticosterone levels, especially in female rats because they have more CBG binding sites to occupy (Tinnikov 1999). Reports that plasma CBG does not follow a circadian rhythm in humans or rats (D'Agostino \& Henning 1982a, Windle et al. 1998, Chung et al. 2016) are consistent with its relatively long plasma half-life of $\sim 14.5$ h (Smith \& Hammond 1991).

In rats, strain differences in HPA axis activity correlate with differences in plasma CBG levels; Fischer 344 rats show higher diurnal and stress corticosterone levels than do Sprague Dawley or Lewis strains, but have higher plasma CBG levels (Dhabhar et al. 1993). Importantly, these strain differences predict an underlying influence of CBG to normalize glucocorticoid receptor occupancy in neural tissue. Differences in HPA axis activity and plasma CBG levels have also been reported across mouse strains (Cabib et al. 1990, Orava et al. 1994, Thoeringer et al. 2007), however their relationship has not been investigated. Notably, two C57Bl/6 mouse lines bred for 'low' and 'high' corticosterone responses to stress had CBG levels that explained this difference (Mattos et al. 2013), demonstrating again how CBG levels determine corticosterone levels and subsequently HPA axis tone.

(c) 2021 Society for Endocrinology Published by Bioscientifica Ltd. Printed in Great Britain
It is, therefore, evident that the HPA axis in rats is more effectively buffered by CBG from fluctuations in corticosterone compared to the human and mouse. Furthermore, it follows that HPA tone is determined by the level of plasma CBG because female rodents not only have greater CBG levels than do males but they also have higher corticosterone levels, and it is not surprising that adrenal size, especially of the zona fasciculata, is larger in females compared to the male to furnish a greater corticosterone output (Sencar-Cupovic \& Milkovic 1976). Thus, plasma CBG levels set by the liver determine the drive on the HPA axis required to normalize steroid exposure or deliver physiologically relevant concentrations of glucocorticoid.

\section{Hepatic enzymes set HPA axis tone}

The liver is the primary site of glucocorticoid clearance, and this function is critical in setting HPA tone. For example, impaired glucocorticoid clearance caused by liver disease results in adrenal insufficiency and suppression of the HPA axis (McNeilly et al. 2010). Two major hepatic glucocorticoid-metabolizing enzymes contribute to HPA tone in this way: $11 \beta$-hydroxysteroid dehydrogenase type 1 (HSD11B1) and hepatic 5 $\alpha$-reductase type 1 (SRD5A1). Metabolic transformations mediated by these hepatic enzymes influence both plasma and intracellular levels of glucocorticoids that can interact with glucocorticoid or mineralocorticoid receptors within their target cells (Chapman et al. 2013, Crowley et al. 2014). Hepatic HSD11B1 is particularly important in setting HPA axis tone as it contributes to plasma cortisol levels in humans by regenerating cortisol from its inert metabolite cortisone, and similarly in rodents through the conversion of 11-dehydrocorticosterone to corticosterone (Chapman et al. 2013). Acting in opposition, hepatic SRD5A1 irreversibly inactivates glucocorticoids to facilitate their clearance (Crowley et al. 2014). Deficiencies in either of these liver enzymes impact 
HPA axis dynamics in mice (Kotelevtsev et al. 1997, Harris et al. 2001, Paterson et al. 2007, Livingstone et al. 2014) and likely have important roles in the development and maturation of the HPA axis in rats and humans, as will be discussed in more detail below.

\section{Early postnatal development (postnatal days 1-15): androgen imprinting and HPT axis maturation}

Interactions between the liver and several endocrine systems are already evident during the first 2 weeks of postnatal life in rats. During this time, testicular testosterone organizes hypothalamic somatostatin (SST) and growth hormone-releasing hormone (GHRH) neurons that influence the liver later in development, and the hypothalamic-pituitary-thyroid (HPT) axis develops as a result of increased hepatic thyroxine-binding globulin (TBG) production (Fig. 1). The ontogenic changes in these systems as it pertains to the HPA axis are as follows.

\section{Neonatal testosterone programs pituitary growth hormone release}

In the hours following birth, male rats experience a surge of testosterone that exerts a multitude of organizational effects in the hypothalamus and pituitary, including that on GH-secreting somatotrophs (Murray et al. 1999, Chowen et al. 2004). The release of GH is regulated by the dynamic actions of hypothalamic GHRH and SST, which act to stimulate and inhibit $\mathrm{GH}$ release from the anterior
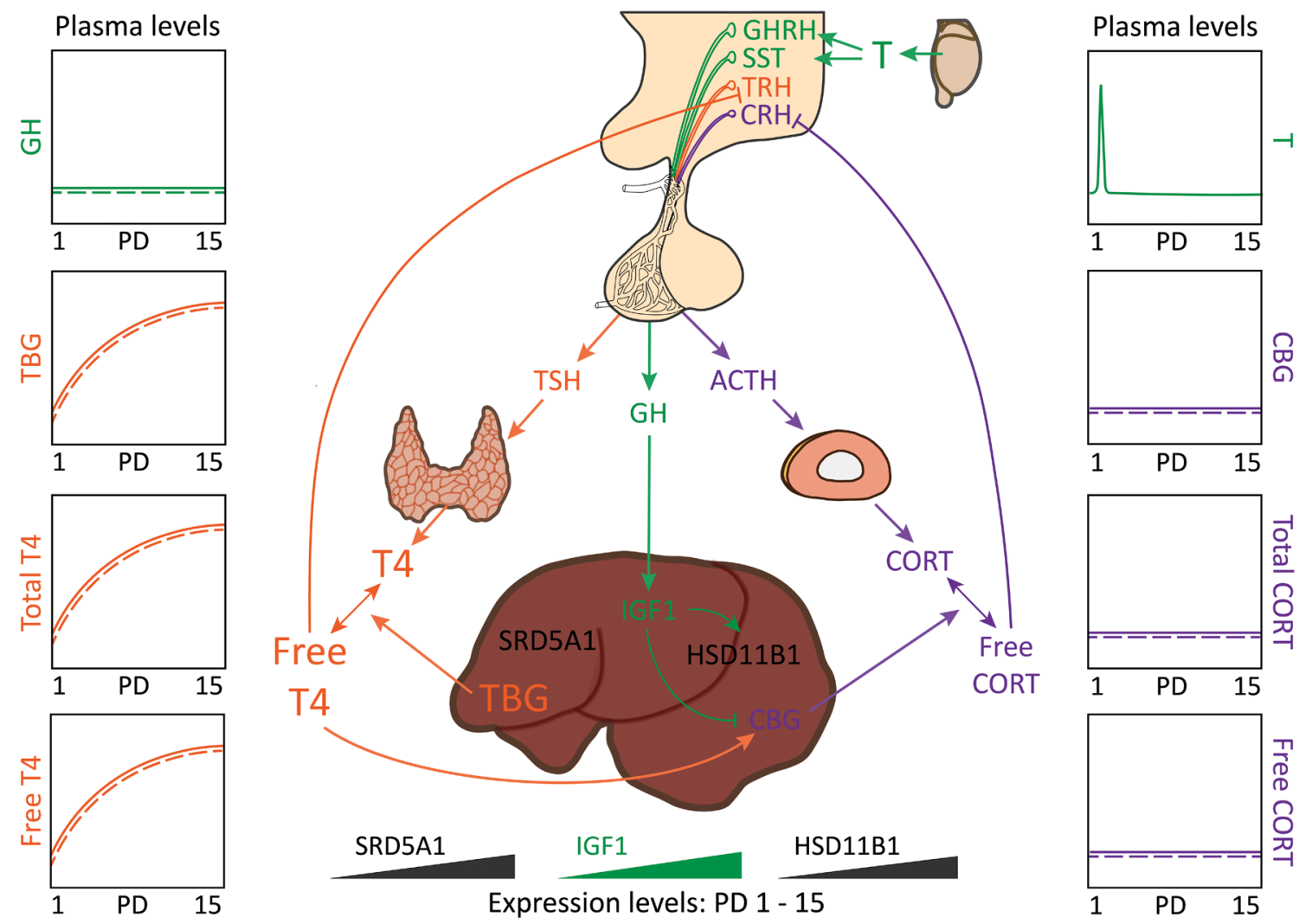

\section{Figure 1}

Early postnatal development: androgen imprinting and HPT maturation. Three endocrine axes that interact with the liver are highlighted by color: SST-GH-T (green), HPT (orange), and HPA (purple). Charts depict plasma levels of key components with respect to postnatal age in males (solid line) and females (dashed line). During postnatal days 1-15, neonatal exposure of males to testosterone programs hypothalamic GHRH and SST neurons in a sexually dimorphic manner that will become apparent during puberty. The HPT axis matures rapidly in both sexes due to increases in hepatic TBG production that drive increases in thyroid hormone levels. Sub-threshold levels of thyroid hormone, IGF1 and HSD11B1 may explain low plasma CBG levels during this time, which in turn explains low CORT levels in both sexes. HPT, hypothalamic-pituitary-thyroid; HPA, hypothalamic-pituitary-adrenal; $\mathrm{PD}$, postnatal day; $\mathrm{GH}$, growth hormone; TBG, thyroxine-binding globulin; $\mathrm{T}$, thyroxine; $\mathrm{T}$, testosterone; $\mathrm{CBG}$, corticosteroid-binding globulin; CORT, corticosterone; GHRH, growth hormone releasing hormone; SST, somatostatin; TRH, thyroxine-releasing hormone; $\mathrm{CRH}$, corticosteroid-releasing hormone; TSH, thyroxine-stimulating hormone; ACTH, adrenocorticotropic hormone; IGF1, insulin-like growth factor 1; SRD5A1, 5 $\alpha$-reductase 1; HSD11B1, 11ß-hydroxysteroid dehydrogenase 1. 
pituitary, respectively (Wagner et al. 1998, Low et al. 2001). Sex differences in the number of GHRH and SST neurons that appear during adulthood are responsible for sex differences in GH secretion patterns, with adult males having more frequent higher amplitude secretory pulses than adult females (Tannenbaum \& Martin 1976, Edén 1979).

During the early postnatal period, sex differences in $\mathrm{GH}$ release are not yet apparent but testosterone exposure on the first day of life will determine the sex-specific pattern of GH release in adulthood (Murray et al. 1999, Chowen et al. 2004). For example, prevention of the neonatal testosterone surge by gonadectomy on the day of birth feminizes the GH secretory pattern by reducing GHRH and SST mRNA levels as well as the number of hypothalamic GHRH neurons (Chowen et al. 1996). Similarly, neonatal testosterone exposure masculinizes $\mathrm{GH}$ release in the female rat by increasing hypothalamic SST mRNA (Chowen et al. 1996). Importantly, the organizational influence of testosterone only occurs after its local conversion to estradiol by aromatase in the brain, as evidenced by the masculinizing effect of exogenous estradiol and the lack of effect by the non-aromatizable androgen dihydrotestosterone (Simonian et al. 1998). The neonatal testosterone surge therefore establishes the sexual dimorphism of hypothalamic and pituitary mediators of $\mathrm{GH}$ pulsatility that emerge as testicular testosterone production resumes at puberty. This results in sex-specific patterns of GH pulsatility that affect hepatic gene expression differently during the period of pubertal to adult transition, as described below.

\section{Early postnatal HPA 'hyporesponsivity' reflects low CBG levels}

The first 2 postnatal weeks have been termed the 'stress hyporesponsive period' because of an apparent inability of the rat neonate to show adult-like elevations in corticosterone in response to stress (Sapolsky \& Meaney 1986). While the adrenal gland is hyporesponsive to ACTH stimulation during this time (Yoshimura et al. 2003), the rest of the HPA axis is functionally intact, for example, changes occur in the expression of $\mathrm{CRH}$ mRNA, plasma ACTH and corticosterone in response to stress (Dallman 2000, Dent et al. 2000). Furthermore, the degree of HPA axis activation as assessed by GR occupancy and nuclear translocation in the brain is comparable in rats of all ages, including the neonate (Viau et al. 1996). It is now understood that the small increases in plasma corticosterone in the neonate reflect the limited hepatic expression of SerpinA6 and the very low plasma CBG levels at this time (Henning 1978, D'Agostino \& Henning 1981, Smith \& Hammond 1991, Viau et al. 1996), as less adrenal corticosterone output is required at this stage to maintain free corticosterone levels. This activity of the HPA axis is also reflected in the low expression level of $H s d 11 b 1$ and Srd5a1, which steadily increase in expression from birth to adulthood (Hundertmark et al. 1994, Yu et al. 2014). Thus, the HPA axis is active during PDs 1-15 although its components are lower in number and concentration.

\section{Postnatal maturation of the HPT axis}

The liver produces another important plasma hormone carrier, thyroxine binding globulin (TBG), which binds the majority of thyroxine (T4) in the circulation (75\% in humans) with high affinity (Savu et al. 1987, Vranckx et al. 1990b). Plasma TBG plays an important role in controlling the HPT axis, a neuroendocrine network that undergoes rapid maturation after birth to promote the development of many organ systems (Zoeller et al. 2007). Like CBG, TBG is a SERPIN family member with gene name SerpinA7, and is exclusively expressed in the rat liver between postnatal days (PDs) 3-45, peaking at day 15 and declining thereafter to low levels until senescence (Vranckx et al. 1990a, Savu et al. 1991). A similar developmental pattern is observed in humans (Refetoff 2000), although TBG levels are still relatively high in adulthood (180-350 nM) whereas in adult rats they are less than $15 \mathrm{nM}$ (Emerson et al. 1993). This change in hepatic TBG production with respect to age suggests that it plays an important role in the maturation of the HPT axis.

Within the HPT axis, thyrotropin-releasing hormone (TRH) is released from the hypothalamus in response to low circulating thyroid hormone levels, promoting thyroidstimulating hormone (TSH) secretion by thyrotrophs in the anterior pituitary (Ortiga-Carvalho et al. 2016). Notably, hypothalamic TRH neurons are located in proximity to $\mathrm{CRH}$ neurons and are also glucocorticoidsensitive, suggesting that these systems interact at the hypothalamic level (Cintra et al. 1990). Circulating TSH acts on the thyroid to produce predominantly $\mathrm{T} 4$, which is converted to its active form triiodothyronine (T3) in peripheral tissue, and the access of thyroid hormones to their target tissues is influenced by TBG. Other liverexpressed plasma proteins, transthyretin and albumin, also bind thyroid hormones in the human and rodent (15 and 10\% of human plasma T4, respectively) but with much lower affinity than TBG (Rabah et al. 2019) and 
they do not appear to be required for thyroid hormone homeostasis in humans (Woeber \& Ingbar 1968).

Significant increases in plasma TBG concentrations during the first 2 postnatal weeks in rats facilitate increases in total and free T4 (Dussault \& Labrie 1975, Walker et al. 1980) that are critical for the developing brain and other organ systems. From this perspective, the liver controls the maturation of the HPT axis through modulation of plasma TBG production. Importantly, thyroid hormones represent one of the major endocrine regulators of hepatic SerpinA6 expression and plasma CBG levels, and sub-threshold thyroid hormone levels during this time may in part explain the low plasma CBG levels and HPA axis 'hyporesponsivity' from PDs 1 to 15 in the rat (Dussault \& Labrie 1975), revealing how the liver uses cues from the HPT axis to initiate HPA axis development (Fig. 1).

\section{Juvenile period (postnatal days 15-30): HPA activation by thyroid hormone}

During the juvenile period in rats, gonadal testosterone production is quiescent (Bell 2018), while high thyroid hormone levels promote the up-regulation of CBG production in the liver required to mature the HPA axis (Fig. 2).

\section{Thyroid hormones stimulate hepatic CBG production and HPA axis development}

A critical threshold of plasma T4 established around PD 15 may explain the observed decline in plasma TBG at this time, since TBG is negatively regulated by thyroid hormones in adult rats (Savu et al. 1992). This threshold may also be achieved due to increased expression of
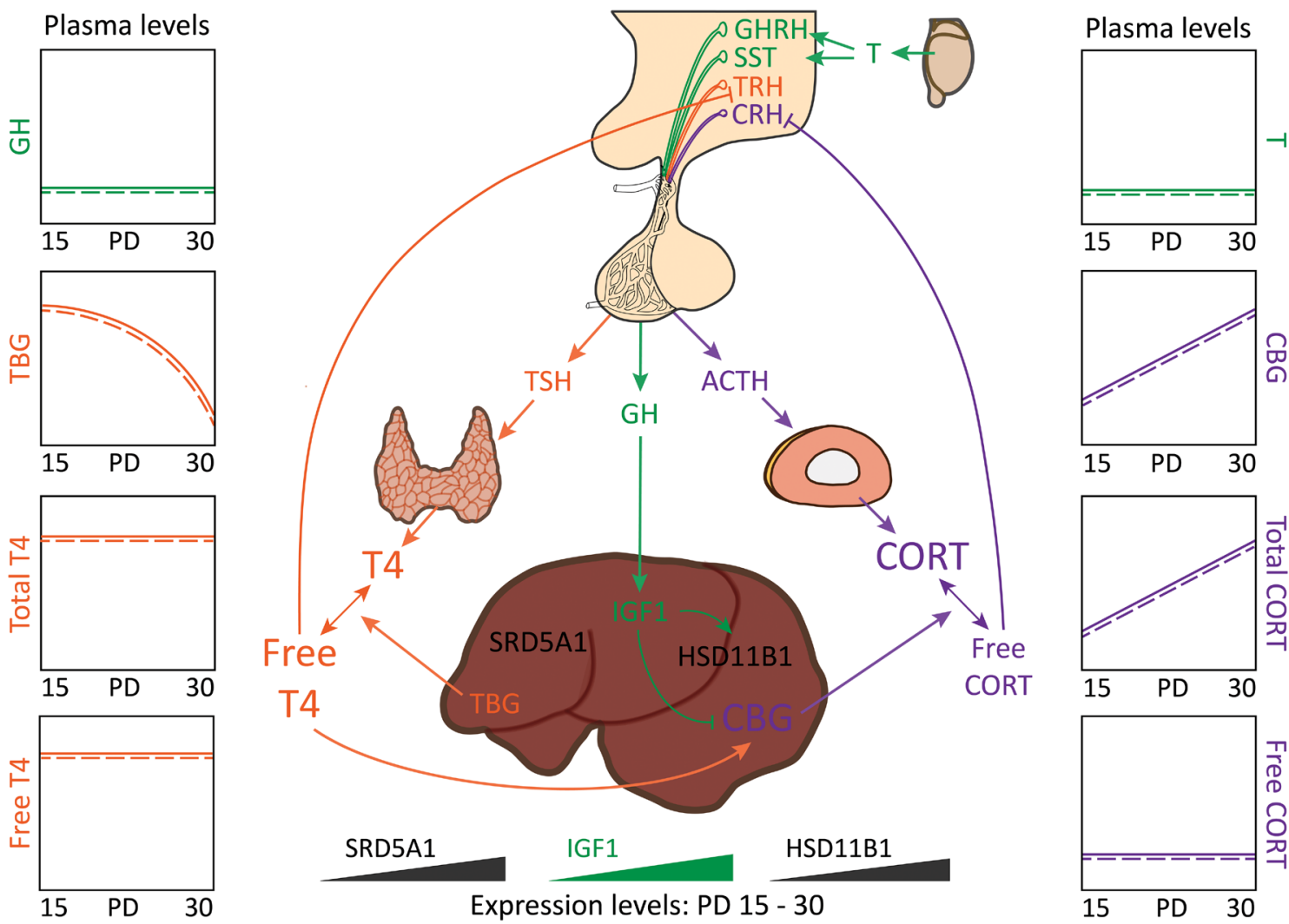

Expression levels: PD $15-30$
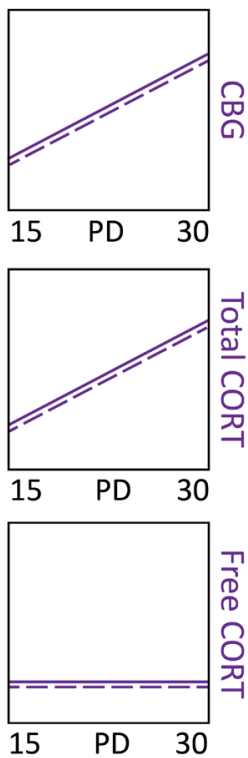

\section{Figure 2}

The juvenile period: HPA activation by thyroid hormone. Three endocrine axes that interact with the liver are highlighted by color: SST-GH-T (green), HPT (orange), and HPA (purple). Charts depict plasma levels of key components with respect to postnatal age in males (solid line) and females (dashed line). During postnatal days 15-30, plasma TBG levels decline while total and free T4 remain high, driving hepatic CBG production. Increases in plasma CBG levels facilitate increased CORT production and adrenal growth. In this way, the HPA axis is activated and matures in both sexes. HPT, hypothalamicpituitary-thyroid; HPA, hypothalamic-pituitary-adrenal; PD, postnatal day; GH, growth hormone; TBG, thyroxine-binding globulin; T4, thyroxine; T, testosterone; CBG, corticosteroid-binding globulin; CORT, corticosterone; GHRH, growth hormone releasing hormone; SST, somatostatin; TRH, thyroxinereleasing hormone; $\mathrm{CRH}$, corticosteroid-releasing hormone; $\mathrm{TSH}$, thyroxine-stimulating hormone; $\mathrm{ACTH}$, adrenocorticotropic hormone; IGF1, insulin-like

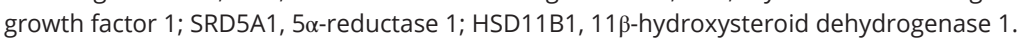


iodothyronine deiodinase type 1 , the primary hepatic enzyme that facilitates the conversion of $\mathrm{T} 4$ to $\mathrm{T} 3$, since the transcript levels of this enzyme reach adult levels between PD 10 and 20 in rats (Bates et al. 1999).

High total and free T4 levels around PD 15 are thought to induce hepatic SerpinA6 expression, as evidenced by thyroid hormone-induced increases in plasma CBG levels in juvenile rats (D'Agostino \& Henning 1982b) and hepatic CBG mRNA and plasma levels in adult male rats (Smith \& Hammond 1991). Furthermore, TSH is the only anterior pituitary hormone that rescues low CBG levels in hypophysectomized adult female rats, demonstrating that CBG levels are modulated by the activity of the HPT axis (Gala \& Westphal 1966b). Rising corticosterone levels during PDs 15-30 may further suppress hepatic TBG production, since TBG is negatively regulated by corticosterone, as shown by adrenalectomized male and female rats that have high TBG levels which normalize after corticosterone replacement (Emerson et al. 1993).

The requirement for proper thyroid function in HPA axis development in rodents is further supported by reports that hypothyroid male rats have lower adrenal weight and plasma corticosterone, and higher ACTH, CRH, and arginine vasopressin (Kamilaris et al. 1991, Tohei 2004). Similarly, hyperthyroidism results in increased plasma corticosterone, CBG, ACTH, POMC mRNA, adrenal sensitivity to ACTH, and accelerated maturation of hypothalamic CRH expression in rats (Kamilaris et al. 1991). Increases in plasma CBG levels drive maturation of the HPA axis during the juvenile period because it introduces demand on the adrenal gland to maintain free corticosterone levels. As a result, adrenal zona fasciculata size and total corticosterone levels increase in parallel with CBG (Gala \& Westphal 1965, Pignatelli et al. 2006). Taken together, increases in thyroid hormone levels facilitated by hepatic TBG production are sensed by the liver, resulting in increased plasma levels of CBG, that in turn modulate the total and free glucocorticoid hormone levels in the circulation that act to promote the activation and maturation of HPA axis (Fig. 2).

\section{Pubertal to adult transition (postnatal days 30-60): sexual dimorphism of the HPA axis}

At the pubertal to adult transition, the production and metabolism of glucocorticoids become sexually dimorphic in rodents, resulting in much higher total corticosterone levels in females (Fig. 3). This can be largely attributed to the advent of sexually dimorphic patterns of plasma
GH pulsatility as programmed by neonatal testosterone and its differential impact on the production of IGF1, CBG and key glucocorticoid-metabolizing enzymes by the rat liver. Conversely, sex differences within the HPT axis remain minimal in adulthood (Waner \& Nyska 1988, Emerson et al. 1993) and therefore have little influence on the sexual dimorphism of the HPA axis.

\section{Growth hormone pulsatility and its sex-specific effects on CBG levels}

The emergence of sex differences in the pituitary release of GH around PD 33 (Gabriel et al. 1992) plays a major role in establishing sexual dimorphism of the HPA axis and other systems. The sex-specific pattern of GH release in the adult rat is organized by testosterone exposure in early neonatal life, and is triggered by the re-initiation of testicular testosterone production in males at puberty (Jansson et al. 1985a, Chowen et al. 1993, Viau 2002, Goel et al. 2014a). At PD 30 when testosterone and body weight begin to increase to a greater level in males, they begin to exhibit pulsatility in GH secretion by producing peaks of $\sim 200 \mathrm{ng} / \mathrm{mL}$ plasma GH every $\sim 3.5 \mathrm{~h}$ that are followed by 2-h intervals with no GH (Tannenbaum \& Martin 1976). In contrast, females maintain continuous release of GH to establish steady plasma concentrations of $~ 30-60 \mathrm{ng} / \mathrm{mL}$ (Edén 1979). It is therefore thought that the default organization of the SST-GH axis is feminine (Adams et al. 2015), since testosterone input is required to obtain a masculine phenotype.

Importantly, variations in GH pulsatility can account for sex differences in plasma CBG levels and HPA axis activity in rats. Continuous infusion of GH to resemble a feminine pattern of $\mathrm{GH}$ secretion increases plasma CBG in hypophysectomized male and female rats, while intermittent $\mathrm{GH}$ replacement in females to resemble a masculine pattern of GH release either has no effect or suppresses CBG levels (Jansson et al. 1989). It has been reported that SST-deficient mice are feminized, since GH is released in a continuous manner, plasma CBG and corticosterone levels are increased, and the sex difference in adrenal weight is lost (Adams et al. 2015). Furthermore, hypophysectomy and gonadectomy in adult female rats reduce plasma CBG levels whereas hypophysectomy in the male increases plasma CBG, and these effects were seen despite replacement therapy with thyroxine, glucocorticoids, androgen or estrogen (Jansson et al. 1989), suggesting that growth hormone maintains the sexually dimorphic CBG levels. Thus, the sex difference in plasma CBG levels appears to emerge as a consequence 
A Plasma levels
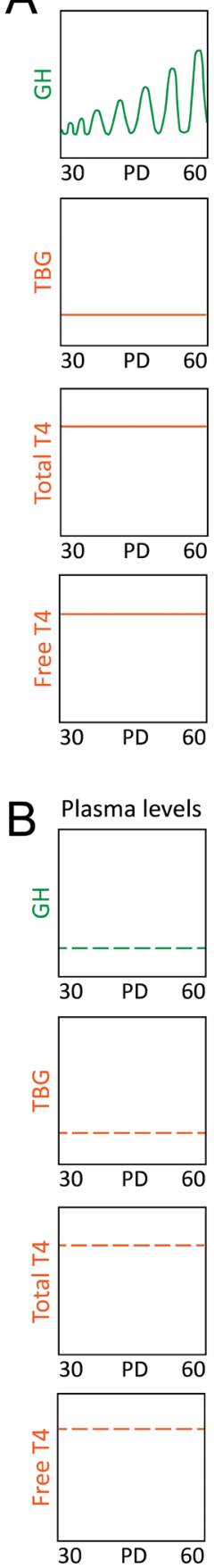

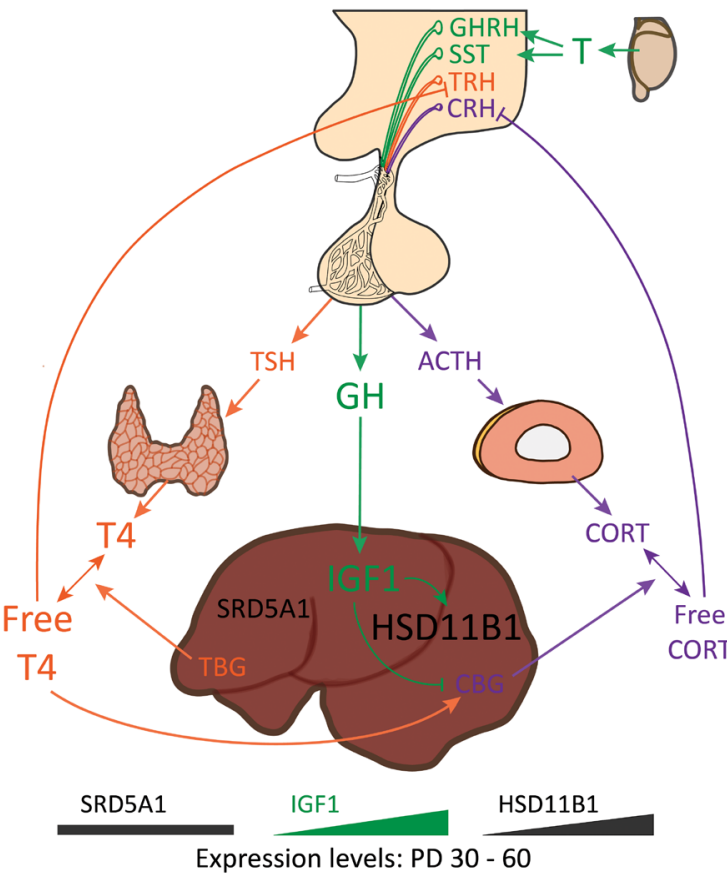

Plasma levels
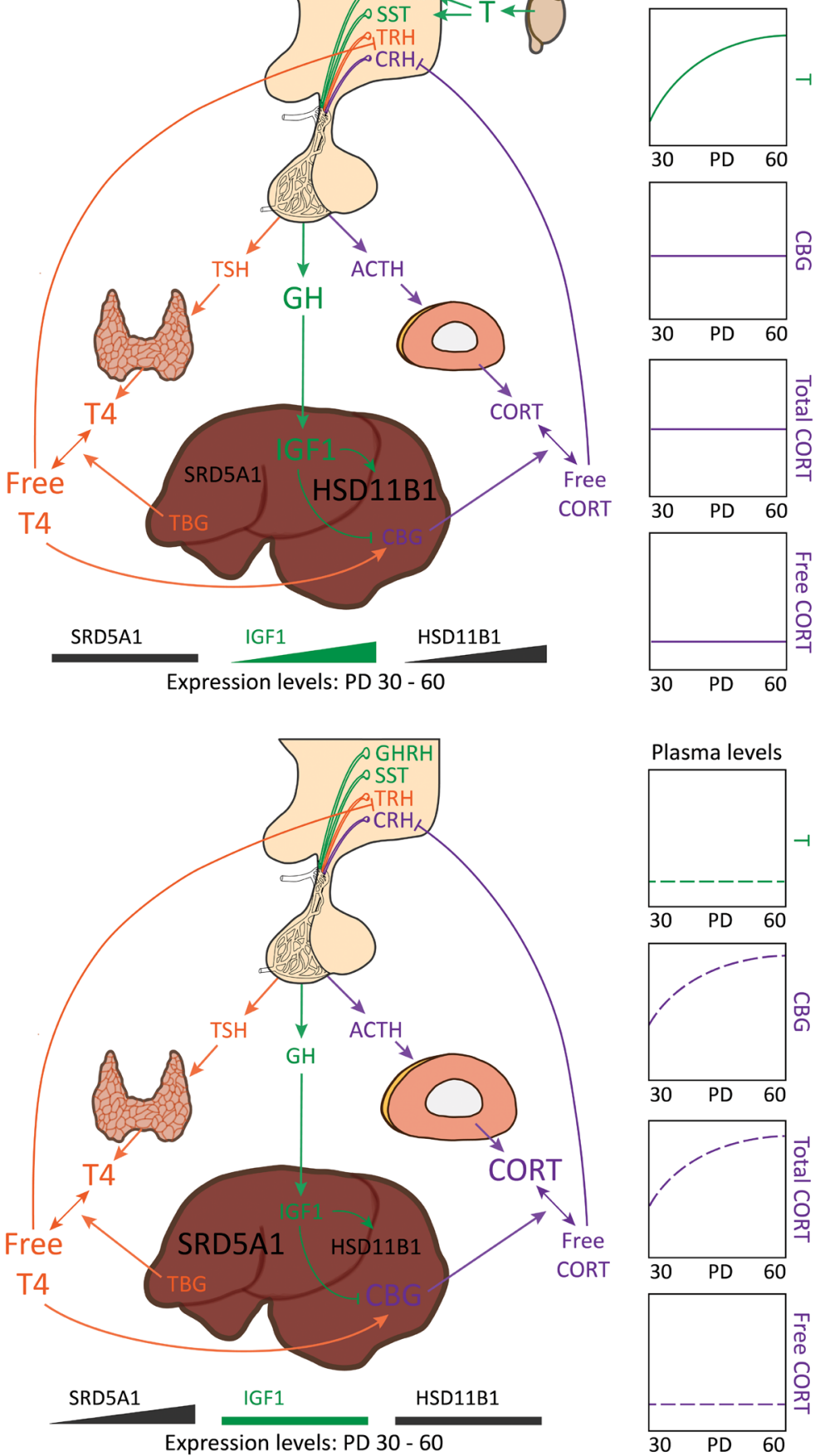

Plasma levels
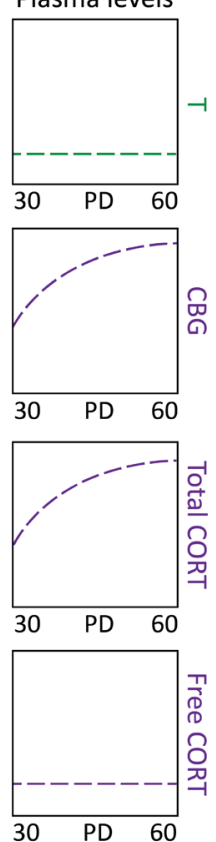

Figure 3

Pubertal to adult transition: sexual dimorphism of the HPA axis. (A) Male. (B) Female. Three endocrine axes that interact with the liver are highlighted by color: SST-GH-T (green), HPT (orange), and HPA (purple). Charts depict plasma levels of key components with respect to postnatal age in males (solid line) and females (dashed line). After postnatal day 30, testosterone levels in the male increase while female levels remain low. Testosterone stimulates the neonatally programmed SST and GHRH neurons to induce a pulsatile release of GH from the anterior pituitary of the male, while the female maintains continuous release. Sexually dimorphic GH patterns are sensed by the liver, causing sex differences in the abundances of IGF1, CBG, HSD11B1 and SRD5A1. Higher plasma CBG in females causes greater plasma CORT levels and adrenal size compared to the male. Sex differences in the activities of hepatic HSD11B1 and SRD5A1 influence circulating CORT levels, further driving sexual dimorphism throughout the HPA axis. HPT, hypothalamic-pituitarythyroid; HPA, hypothalamic-pituitary-adrenal; PD, postnatal day; GH, growth hormone; TBG, thyroxine-binding globulin; T4, thyroxine; T, testosterone; CBG, corticosteroid-binding globulin; CORT, corticosterone; GHRH, growth hormone releasing hormone; SST, somatostatin; TRH, thyroxine-releasing hormone; $\mathrm{CRH}$, corticosteroid-releasing hormone; TSH, thyroxine-stimulating hormone; ACTH, adrenocorticotropic hormone; IGF1, insulin-like growth factor 1; SRD5A1, 5 $\alpha$-reductase 1; HSD11B1, 11 $\beta$-hydroxysteroid dehydrogenase 1. 
of sexual dimorphism in pituitary GH pulsatility around PD 30 in rats.

\section{Mediation of growth hormone action by IGF1}

Experimental evidence suggests that growth hormone mediates its effects on hepatic CBG expression through the actions of IGF1. In the GH-IGF axis, growth hormone directly stimulates hepatic Igf1 expression and IGF1 suppresses pituitary GH release in a negative feedback manner (Jones \& Clemmons 1995). Hepatic IGF1 mRNA levels increase steadily in the rat until PD 30, when male levels increase markedly in response to the establishment of a pattern of plasma GH pulsatility (Shoba et al. 1999) that departs from IGF1 levels in females (Frystyk et al. 1998). In vitro, IGF1 negatively regulates hepatic SERPINA6 expression (Crave et al. 1995), providing a potential mechanism by which variations in GH pulsatility and subsequently IGF1 affect CBG levels. Interestingly, IGF1 is sensitive to ovarian status, since its mRNA and protein levels are downregulated by estrogen and upregulated by testosterone in ovariectomized rats (Borski et al. 1996), further implicating IGF1 in the development and/or maintenance of sexually dimorphic systems.

\section{HPA axis sexual dimorphism is programmed by neonatal testosterone}

Manipulation of sex steroid hormones during critical perinatal periods can masculinize or feminize the HPA axis. Male rats treated with the antiandrogen flutamide from gestational day 13 to PD 20 show changes in the corticosterone secretion pattern and brain HPA markers that reflect feminization (Seale et al. 2005). Adult CBG levels are also influenced by neonatal androgen exposure: male rats castrated at birth develop feminized plasma CBG levels in adulthood, and animals of both sexes gonadectomized at birth and treated with testosterone propionate have very low CBG levels in adulthood (Van Baelen et al. 1977, Jansson et al. 1989). Interestingly, gonadectomy on day 25 also increased CBG levels in males although to a lesser extent than when performed at birth, and testosterone replacement reversed these effects (Jansson et al. 1989), demonstrating that both the organizational effects of neonatal testosterone and the activational effects of pre-pubertal testosterone are required to establish sexual dimorphism of the HPA axis. Furthermore, testosterone in adulthood is known to suppress CBG and HPA axis activity in females, whereas estradiol is stimulatory in males (Gala \& Westphal 1966a,
Viau 2002, Viau \& Meaney 2004, McCormick \& Mathews 2010, Goel et al. 2014a). The contribution of chromosomal sex vs gonadal hormones to the sexual dimorphism of the HPA axis remains unknown. However, some studies have utilized the four core genotypes mouse model to show that sex differences in the morphology of arginine vasopressin fibres in the lateral septum - a region known to influence the HPA axis - is caused by both chromosomal sex and gonadal hormone exposure (Gatewood et al. 2006, Arnold \& Chen 2009). The organizational influences of gonadal steroids on the HPA axis may be mediated by GH pulsatility, to explain lower plasma CBG levels, reduced adrenal size and lower corticosterone concentrations in males than in females (Gala \& Westphal 1965, Henning 1978, Smith \& Hammond 1991, Pignatelli et al. 2006). However, this remains to be seen since GH pulsatility patterns were not measured in studies relating neonatal testosterone exposure to adult HPA axis function.

Plasma ACTH has trophic effects on the adrenal gland, but plasma ACTH levels are not sexually dimorphic in adult rats and therefore cannot explain sex differences in adrenal gland size (Goel et al. 2014b). This has led to the hypothesis that sex differences in adrenal size emerge due to differences in adrenal sensitivity to ACTH (Goel et al. $2014 b$ ). However, the actions of CBG at the adrenal gland may also play a key role in determining adrenal size, since evidence suggests corticosterone represses steroidogenesis in the adrenal itself (Spiga et al. 2017). It may therefore be envisaged that CBG acts to reduce intra-adrenal negative feedback, especially in females where the higher plasma CBG levels accentuate the local release and removal of corticosterone from the adrenal cells, thereby promoting adrenal cortical expression of transcription factors such as SF-1 and DAX-1 that regulate both steroidogenesis and adrenal growth (Spiga et al. 2017).

\section{GH-sensitive hepatic steroid-metabolizing enzymes maintain HPA sexual dimorphism}

Growth hormone induces sex differences in HPA axis tone by affecting plasma CBG levels, but also by changing the expression of hepatic glucocorticoid-metabolizing enzymes that contribute to the regulation of plasma glucocorticoid levels: HSD11B1 and SRD5A1 (Fig. 3).

\section{1ß-hydroxysteroid dehydrogenase 1 (HSD11B1)}

The enzyme HSD11B1 regenerates active glucocorticoid by converting inert cortisone or 11-dehydrocorticosterone to active cortisol and corticosterone, respectively. It is most abundant in the liver but can be found in many tissues 
throughout the body including adipose, hippocampus, hypothalamus and pituitary (Chapman et al. 2013). Since HSD11B1 acts to amplify local glucocorticoid concentrations independent of circulating concentrations, its action in these tissues leads to increased local glucocorticoid signaling, influencing negative feedback in the brain and metabolic actions in the liver (Harris et al. 2001). Hepatic HSD11B1 contributes to $20-40 \%$ of daily cortisol production in humans and elevations in its activity are thought to up-regulate the glucocorticoidsensitive processes of gluconeogenesis and fatty acid oxidation (Masuzaki \& Flier 2003, Basu et al. 2004, Walker \& Andrew 2006, Maniam et al. 2014).

The isozyme HSD11B2 performs the reverse reaction that inactivates glucocorticoid. Its major functions are in the kidney where it ensures aldosterone is the prevailing substrate of the MR, and in the placenta where it protects the fetus from excessive glucocorticoid exposure. The actions of HSD11B2 during early life can influence the programming of the HPA axis: adult offspring of rats treated with an HSD11B inhibitor show increased basal glucocorticoid levels, increased CRH and reduced GR mRNA in the hypothalamic paraventricular nucleus (Welberg et al. 2000), and Hsd11b2-/- mice have smaller adrenal glands and heightened anxiety (Holmes et al. 2006). The activities of HSD11B2 would alter substrate availability for HSD11B1 in tissues where it is expressed, but its hepatic expression is minimal in humans, rats and mice (Chapman et al. 2013, Yu et al. 2014), suggesting HSD11B2 is unlikely to influence circulating glucocorticoid levels. Thus, hepatic HSD11B1 is the crucial determinant of intracellular and circulating glucocorticoid availability, and the developmental regulation of its production in the liver is determined by the same endocrine systems that control other major components of the HPA axis (Maniam et al. 2014), as will be discussed.

Direct manipulation of $H s d 11 b 1$ expression in vivo has mostly been performed in male mice. All strains of mice lacking HSD11B1 have larger adrenals and exaggerated corticosterone responses to stress compared to their WT littermates, and this changein adrenal size is thought to occur as compensation to replace glucocorticoid that is normally regenerated by hepatic HSD11B1. Basal corticosterone levels are either unchanged (Lavery et al. 2012, Morgan et al. 2014, Yau et al. 2015) or increased (Kotelevtsev et al. 1997, Harris et al. 2001) in HSD11B1-deficient mice, and these contrasting observations may reflect strain differences: C57Bl/6 mice show increases in GR mRNA at negative feedback sites and a lesser degree of adrenal hypertrophy compared to 129/MF1 mice, which may explain and/or reflect the unchanged corticosterone levels (Carter et al. 2009). Interestingly, C57Bl/6 mice overexpressing Hsd11b1 in the liver crossed with global Hsd11b1-deficient mice to selectively restore hepatic HSD11B1 production rescues all of the HPA axis defects, including circadian and stressinduced plasma corticosterone levels (Paterson et al. 2007). These data implicate hepatic HSD11B1 as a key player in HPA axis regulation and suggests that it contributes to the development and sexually dimorphic activity of the HPA axis in rats as well.

Several hepatic glucocorticoid-metabolizing enzymes are sexually dimorphic and programmed by neonatal sex steroids (Einarsson et al. 1973). Hepatic Hsd11b1 expression increases near parturition in rats and progressively with advancing postnatal age (Hundertmark et al. 1994), becoming sexually dimorphic as sex differences in GH pulsatility are achieved (Low et al. 1994). The feminine GH pattern of continuous pituitary release results in 50\% lower HSD11B1 mRNA and activity in the female liver compared to male (Low et al. 1994, Ahluwalia et al. 2004), and this is thought to be mediated by IGF1 (Chapman et al. 2013). Greater intracellular glucocorticoid levels in the male may explain reduced CBG levels since glucocorticoids directly suppress CBG production (Feldman et al. 1979, Schlechte \& Hamilton 1987). Thus, sexual dimorphism in hepatic HSD11B1 activity provides an explanation for sex differences in hepatic and plasma corticosterone levels, as well as the negative feedback regulation of CBG production.

Dwarf rats congenitally deficient in GH lack sex differences in HSD11B1 activity, and administration of continuous GH to males decreases hepatic HSD11B1 activity and gene expression. Similarly, continuous $\mathrm{GH}$ administration to hypophysectomized dwarf rats attenuates hepatic HSD11B1 activity and gene expression (Low et al. 1994). Sex steroids may also regulate HSD11B1, since testosterone administration to gonadectomized rats of either sex induces masculine activity levels (Lax et al. 1978), and estradiol at pharmalogical doses represses hepatic Hsd11b1 expression and activity (Jamieson et al. 1999). Last, thyroid hormone has sex-specific effects since its administration reduces hepatic HSD11B1 activity in males but increases its activity in females (Liu et al. 1997). Regulation of hepatic Hsd11b1 expression by the same endocrine factors which control other HPA axis components implicate HSD11B1 as a key player in the age-, sex- and context-specific actions of the HPA axis.

\section{5 $\alpha$-reductase 1 (SRD5A1)}

Glucocorticoids are irreversibly inactivated by $5 \alpha$-reductase in the liver, and SRD5A1 is involved in the control of 
cellular and circulating glucocorticoid levels and therefore has implications in the development and function of the HPA axis (Nixon et al. 2012, Crowley et al. 2014). The SRD5A1 enzyme is expressed highly in human and rodent livers and at lower levels in the adrenal and brain, including within afferent mediators to the HPA axis and sites of glucocorticoid negative feedback (Nixon et al. 2012). Its major substrates are cortisol, corticosterone, testosterone and progesterone and their catabolism by SRD5A1 in the liver plays an important role in their plasma clearance (Nixon et al. 2012), as illustrated in SRD5A1-deficient mice that have an eight-fold slower clearance of corticosterone (Livingstone et al. 2014) and display intrahepatic accumulations of glucocorticoids (Dowman et al. 2013). In these SRD5A1-deficient mice, resting plasma corticosterone levels and adrenal weight are normal and chronic infusion of corticosterone does not alter plasma corticosterone levels compared to WT mice. However, the corticosterone response to ACTH and stress is notably reduced, suggesting that enhanced negative feedback by corticosterone resulting from its impaired peripheral clearance causes a compensatory downregulation of the HPA axis in SRD5A1 deficiency. The effects of SRD5A1 deficiency may manifest differently across strains and species given that only the C57B16/ SvEv/129 mouse background has been investigated. Notably, the phenotype of SRD5A1-deficient mice is similar to that seen in HSD11B1-deficient mice on the same 129/MF1 background (Livingstone et al. 2014). In addition to the tissues mentioned above, human SRD5A1 is expressed in numerous others including adipose, kidney, intestine, lymph nodes and thyroid (Fagerberg et al. 2014), expanding the sites of glucocorticoid metabolism that will likely influence HPA tone differently compared to the rat.

Hepatic expression of $\operatorname{Srd5a1}$ is sexually dimorphic in the rat, with approximately 20-fold higher mRNA and activity in females (Andersson et al. 1989). In males, testosterone negatively regulates SRD5A1, since gonadectomy of neonatal and pre-pubertal male rats increases hepatic SRD5A1 transcripts or activity (Jansson et al. 1985b), and gonadectomy of sexually mature male rats also increases SRD5A1 mRNA (El-Awady et al. 2004), explaining their low expression levels compared to the female. In females, the regulation of hepatic SRD5A1 by testosterone is less clear since adult females treated with testosterone have even higher SRD5A1 levels than normal, and adult ovariectomy also increases Srd5a1 mRNA (Torres \& Ortega 2004). However, when females are masculinized by neonatal gonadectomy followed by testosterone treatment in adulthood, hepatic SRD5A1 levels are reduced, revealing the organizational effects of testosterone on the regulation of Srd5a1 (Jansson et al. 1985b). These observations also implicate GH pulsatility in determining SRD5A1 levels, since GH release patterns were masculinized by these manipulations (Jansson et al. 1985b). Indeed, continuous infusion of GH increases hepatic SRD5A1 activity in hypophysectomized, hypothyroid males, and to a greater extent than in hypophysectomized, euthyroid males (Jansson et al. 1985b), demonstrating the influences of both GH pulsatility and thyroid hormone on SRD5A1. The sensitivity of corticosterone metabolism to thyroid hormone, GH, and sex steroids predict that changes in hepatic Srd5a1 expression may also contribute to the development and sexual dimorphism of the HPA axis.

\section{Conclusions}

Organ development is an energetically demanding process that relies on cues to trigger progression, and the liver provides many of these cues concurrently with its fundamental role in maintaining metabolic homeostasis. This review introduces a framework for understanding the mechanisms behind the postnatal ontogeny and sexual dimorphism of the HPA axis in rats, advancing the concept that the liver is an important mediator of these processes. Specifically, the liver integrates endocrine signals from the SST-GH-testosterone, HPT, and HPA axes to modulate the expression of the major plasma binding proteins for thyroid hormone and glucocorticoids, TBG and CBG, respectively, as well as hepatic glucocorticoidand thyroid hormone-metabolizing enzymes HSD11B1, SRD5A1 and iodothyronine deiodinases that in turn regulate these same endocrine regulatory axes to promote their maturation. Developmental changes in the activities of these endocrine systems as coordinated by the liver are key to age-, sex- and context-dependent physiological responses critical for homeostatic control, which is essential for survival and propogation of species.

\section{Comparisons to humans}

Rats are a preferred model of human disease because their physiology, cognitive abilities and behavioral responses better resemble the human, compared to mice (Iannaccone \& Jacob 2009). Many of the endocrine interactions reviewed here with respect to postnatal HPA axis development are conserved in humans, though 
the literature in humans is less consistent due to the diversity of demography, age and health status, time and source of sampling, and the type of stimulus (Goel et al. 2014b). Both human and rat acquire sex differences in HPA activity during puberty (Kudielka et al. 2004, Goel et al. 2014b) and this can be explained by the activities of sex hormones; fetal testosterone levels correlate with neurodevelopmental disease risk and behavioral stress reactivity (Gore et al. 2014), and certain stress-related disorders such as depression and anxiety are more prevalent in women (Albert 2015). In humans, the sex difference in GH secretion is less pronounced compared to the rat, and also reversed, such that females secrete more GH due to more pulses (Hartman et al. 1990). Despite this, adults with GH deficiency show an effect of GH replacement to decrease plasma IGF1, CBG and cortisol, with no change in thyroid hormone or thyroxine-binding globulin levels (Tschöp et al. 2000); interactions that are consistent with the rat. Human GH may have the opposite effect on hepatic HSD11B1, however, since urinary cortisol metabolite profiles suggest GH is inhibitory (Moore et al. 1999), whereas rat GH is stimulatory to HSD11B1 activity (Low et al. 1994, Ahluwalia et al. 2004). Regulation of plasma glucocorticoid concentrations is critical to hepatic and HPA function in humans as in the rat, shown by the prevalence of adrenal insufficiency in cases of liver cirrhosis (McNeilly et al. 2010, Livingstone et al. 2014) and in the development of hepatic insulin resistance and intrahepatic lipid accumulation during SRD5A1 deficiency (Hazlehurst et al. 2016). Notably, human CBG levels are only sexually dimorphic in response to oral contraceptives (Verbeeten \& Ahmet 2018), during pregnancy (Meyer et al. 2016) and aging (Kudielka et al. 2004), which may in part explain the less overt sex differences of the human HPA axis compared to the rat.

Many of the molecular relationships reviewed here have been studied independently, and functional linkages between these factors of interest remain worthy of pursuit. Other regulators of metabolic homeostasis such as the CNS and immune system are, in addition to the liver, critical for HPA function, and their actions have yet to be considered in the context of postnatal HPA axis development and its sexual dimorphism. Importantly, knowledge of the interplay between the liver, HPT, and HPA axes in postnatal rats can advance our understanding of pathophysiologies related to the HPA axis in humans, and sex differences in the rodent HPA axis offer a useful model of interindividual and sex differences in the development and function of the human HPA axis.

\section{Declaration of interest}

The authors declare that there is no conflict of interest that could be perceived as prejudicing the impartiality of this review.

\section{Funding}

This work was supported by the Natural Sciences and Engineering Research Council of Canada and the Canadian Institutes of Health Research (VV), and by a UBC Faculty of Medicine CELL Program Award (JNCT).

\section{Acknowledgement}

The author wishes to thank Dr Mark Nixon at the University of Edinburgh for his critical review of this manuscript.

\section{References}

Adams JM, Otero-Corchon V, Hammond GL, Veldhuis JD, Qi N \& Low MJ 2015 Somatostatin is essential for the sexual dimorphism of GH secretion, corticosteroid-binding globulin production, and corticosterone levels in mice. Endocrinology 156 1052-1065. (https:// doi.org/10.1210/en.2014-1429)

Ahluwalia A, Clodfelter KH \& Waxman DJ 2004 Sexual dimorphism of rat liver gene expression: regulatory role of growth hormone revealed by deoxyribonucleic acid microarray analysis. Molecular Endocrinology 18 747-760. (https://doi.org/10.1210/me.2003-0138)

Albert PR 2015 Why is depression more prevalent in women? Journal of Psychiatry and Neuroscience 40 219-221. (https://doi.org/10.1503/ jpn.150205)

Andersson S, Bishop RW \& Russell DW 1989 Expression cloning and regulation of steroid 5 alpha-reductase, an enzyme essential for male sexual differentiation. Journal of Biological Chemistry 264 16249-16255.

Arnold AP \& Chen X 2009 What does the 'four core genotypes' mouse model tell us about sex differences in the brain and other tissues? Frontiers in Neuroendocrinology 30 1-9. (https://doi.org/10.1016/j. yfrne.2008.11.001)

Basu R, Singh RJ, Basu A, Chittilapilly EG, Johnson CM, Toffolo G, Cobelli C \& Rizza RA 2004 Splanchnic cortisol production occurs in humans: evidence for conversion of cortisone to cortisol via the 11-beta hydroxysteroid dehydrogenase (11beta-hsd) type 1 pathway. Diabetes 53 2051-2059. (https://doi.org/10.2337/ diabetes.53.8.2051)

Bates JM, St Germain DL \& Galton VA 1999 Expression profiles of the three iodothyronine deiodinases, D1, D2, and D3, in the developing rat. Endocrinology 140 844-851. (https://doi.org/10.1210/ endo.140.2.6537)

Bell MR 2018 Comparing postnatal development of gonadal hormones and associated social behaviors in rats, mice, and humans. Endocrinology 159 2596-2613. (https://doi.org/10.1210/en.201800220)

Bolton JL, Hayward C, Direk N, Lewis JG, Hammond GL, Hill LA, Anderson A, Huffman J, Wilson JF, Campbell H, et al. 2014 Genome wide association identifies common variants at the SERPINA6/ SERPINA1 locus influencing plasma cortisol and corticosteroid binding globulin. PLoS Genetics 10 e1004474. (https://doi. org/10.1371/journal.pgen.1004474)

Borski RJ, Tsai W, DeMott-Friberg R \& Barkan AL 1996 Regulation of somatic growth and the somatotropic axis by gonadal steroids: primary effect on insulin-like growth factor I gene expression and 
secretion. Endocrinology 137 3253-3259. (https://doi.org/10.1210/ endo.137.8.8754747)

Bourke CH, Harrell CS \& Neigh GN 2012 Stress-induced sex differences: adaptations mediated by the glucocorticoid receptor. Hormones and Behavior 62 210-218. (https://doi.org/10.1016/j.yhbeh.2012.02.024)

Buschdorf JP \& Meaney MJ 2015 Epigenetics/programming in the HPA axis. Comprehensive Physiology 6 87-110. (https://doi.org/10.1002/ cphy.c140027)

Cabib S, Algeri S, Perego C \& Puglisi-Allegra S 1990 Behavioral and biochemical changes monitored in two inbred strains of mice during exploration of an unfamiliar environment. Physiology and Behavior 47 749-753. (https://doi.org/10.1016/0031-9384(90)90089-m)

Carter RN, Paterson JM, Tworowska U, Stenvers DJ, Mullins JJ, Seckl JR \& Holmes MC 2009 Hypothalamic-pituitary-adrenal axis abnormalities in response to deletion of 11beta-HSD1 is strain-dependent. Journal of Neuroendocrinology 21 879-887. (https://doi.org/10.1111/j.13652826.2009.01899.x

Chapman K, Holmes M \& Seckl J 2013 11ß-Hydroxysteroid dehydrogenases: intracellular gate-keepers of tissue glucocorticoid action. Physiological Reviews 93 1139-1206. (https://doi.org/10.1152/ physrev.00020.2012)

Chowen JA, Argente J, Gonzalez-Parra S \& Garcia-Segura LM 1993 Differential effects of the neonatal and adult sex steroid environments on the organization and activation of hypothalamic growth hormone-releasing hormone and somatostatin neurons. Endocrinology 133 2792-2802. (https://doi.org/10.1210/ endo.133.6.7902269)

Chowen JA, Garcia-Segura LM, Gonzalez-Parra S \& Argente J 1996 Sex steroid effects on the development and functioning of the growth hormone axis. Cellular and Molecular Neurobiology 16 297-310. (https://doi.org/10.1007/BF02088097)

Chowen JA, Frago LM \& Argente J 2004 The regulation of GH secretion by sex steroids. European Journal of Endocrinology 151 (Supplement 3) U95-U100. (https://doi.org/10.1530/eje.0.151u095)

Chung TT, Gunganah K, Monson JP \& Drake WM 2016 Circadian variation in serum cortisol during hydrocortisone replacement is not attributable to changes in cortisol-binding globulin concentrations. Clinical Endocrinology 84 496-500. (https://doi.org/10.1111/ cen.12982)

Cintra A, Fuxe K, Wikstrom AC, Visser T \& Gustafsson JA 1990 Evidence for thyrotropin-releasing hormone and glucocorticoid receptorimmunoreactive neurons in various preoptic and hypothalamic nuclei of the male rat. Brain Research 506 139-144. (https://doi. org/10.1016/0006-8993(90)91210-8)

Crave JC, Lejeune H, Brébant C, Baret C \& Pugeat M 1995 Differential effects of insulin and insulin-like growth factor I on the production of plasma steroid-binding globulins by human hepatoblastoma-derived (Hep G2) cells. Journal of Clinical Endocrinology and Metabolism 80 1283-1289. (https://doi.org/10.1210/jcem.80.4.7536204)

Crowley RK, Hughes B, Gray J, McCarthy T, Hughes S, Shackleton CH, Crabtree N, Nightingale P, Stewart PM \& Tomlinson JW 2014 Longitudinal changes in glucocorticoid metabolism are associated with later development of adverse metabolic phenotype. European Journal of Endocrinology 171 433-442. (https://doi.org/10.1530/EJE14-0256)

D’Agostino J \& Henning SJ 1981 Hormonal control of postnatal development of corticosteroid-binding globulin. American Journal of Physiology 240 E402-E406. (https://doi.org/10.1152/ ajpendo.1981.240.4.E402)

D'Agostino J \& Henning SJ 1982a Postnatal development of corticosteroid-binding globulin: effects of thyroxine. Endocrinology 111 1476-1482. (https://doi.org/10.1210/endo-111-5-1476)

D'Agostino J \& Henning SJ $1982 b$ Role of thyroxine in coordinate control of corticosterone and CBG in postnatal development. American Journal of Physiology 242 E33-E39. (https://doi.org/10.1152/ ajpendo.1982.242.1.E33)
Dallman MF 2000 Editorial: moments in time - the neonatal rat hypothalamo-pituitary-adrenal axis. Endocrinology 141 1590-1592. (https://doi.org/10.1210/endo.141.5.7527)

de Kloet ER, de Kloet SF, de Kloet CS \& de Kloet AD 2019 Top-down and bottom-up control of stress-coping. Journal of Neuroendocrinology $\mathbf{3 1}$ e12675. (https://doi.org/10.1111/jne.12675)

Deinzer R, Kirschbaum C, Gresele C \& Hellhammer DH 1997 Adrenocortical responses to repeated parachute jumping and subsequent h-CRH challenge in inexperienced healthy subjects. Physiology and Behavior 61 507-511. (https://doi.org/10.1016/s00319384(96)00465-9)

Dent GW, Smith MA \& Levine S 2000 Rapid induction of corticotropinreleasing hormone gene transcription in the paraventricular nucleus of the developing rat. Endocrinology 141 1593-1598. (https://doi. org/10.1210/endo.141.5.7455)

Dhabhar FS, McEwen BS \& Spencer RL 1993 Stress response, adrenal steroid receptor levels and corticosteroid-binding globulin levels - a comparison between Sprague-Dawley, Fischer 344 and Lewis rats. Brain Research 616 89-98. (https://doi.org/10.1016/00068993(93)90196-t)

Dobbing J \& Sands J 1979 Comparative aspects of the brain growth spurt. Early Human Development 3 79-83. (https://doi.org/10.1016/03783782(79)90022-7)

Dowman JK, Hopkins LJ, Reynolds GM, Armstrong MJ, Nasiri M, Nikolaou N, van Houten EL, Visser JA, Morgan SA, Lavery GG, et al. 2013 Loss of 5alpha-reductase type 1 accelerates the development of hepatic steatosis but protects against hepatocellular carcinoma in male mice. Endocrinology 154 4536-4547. (https://doi.org/10.1210/ en.2013-1592)

Duma D, Collins JB, Chou JW \& Cidlowski JA 2010 Sexually dimorphic actions of glucocorticoids provide a link to inflammatory diseases with gender differences in prevalence. Science Signaling 3 ra74. (https://doi.org/10.1126/scisignal.2001077)

Dussault JH \& Labrie F 1975 Development of the hypothalamic-pituitarythyroid axis in the neonatal rat. Endocrinology 97 1321-1324. (https:// doi.org/10.1210/endo-97-5-1321)

Edén S 1979 Age- and sex-related differences in episodic growth hormone secretion in the rat. Endocrinology 105 555-560. (https://doi. org/10.1210/endo-105-2-555)

Einarsson K, Gustafsson JA \& Stenberg A 1973 Neonatal imprinting of liver microsomal hydroxylation and reduction of steroids. Journal of Biological Chemistry 248 4987-4997.

El-Awady MK, El-Garf W \& El-Houssieny L 2004 Steroid 5alpha reductase mRNA type 1 is differentially regulated by androgens and glucocorticoids in the rat liver. Endocrine Journal 51 37-46. (https:// doi.org/10.1507/endocrj.51.37)

Emerson CH, Seiler CM, Alex S, Fang SL, Mori Y \& DeVito WJ 1993 Gene expression and serum thyroxine-binding globulin are regulated by adrenal status and corticosterone in the rat. Endocrinology 133 1192-1196. (https://doi.org/10.1210/ endo.133.3.8365361)

Fagerberg L, Hallström BM, Oksvold P, Kampf C, Djureinovic D, Odeberg J, Habuka M, Tahmasebpoor S, Danielsson A, Edlund K, et al. 2014 Analysis of the human tissue-specific expression by genome-wide integration of transcriptomics and antibody-based proteomics. Molecular and Cellular Proteomics 13 397-406. (https://doi. org/10.1074/mcp.M113.035600)

Feldman D, Mondon CE, Horner JA \& Weiser JN 1979 Glucocorticoid and estrogen regulation of corticosteroid-binding globulin production by rat liver. American Journal of Physiology 237 E493-E499. (https://doi. org/10.1152/ajpendo.1979.237.6.E493)

Frystyk J, Gronbaek H, Skjaerbaek C, Flyvbjerg A, Orskov H \& Baxter RC 1998 Developmental changes in serum levels of free and total insulinlike growth factor I (IGF-I), IGF-binding protein-1 and -3, and the acid-labile subunit in rats. Endocrinology 139 4286-4292. (https://doi. org/10.1210/endo.139.10.6273) 
Gabriel SM, Roncancio JR \& Ruiz NS 1992 Growth hormone pulsatility and the endocrine milieu during sexual maturation in male and female rats. Neuroendocrinology 56 619-625. (https://doi.org/10.1159/000126284)

Gala RR \& Westphal U 1965 Corticosteroid-binding globulin in the rat: studies on the sex difference. Endocrinology 77 841-851. (https://doi. org/10.1210/endo-77-5-841)

Gala RR \& Westphal U 1966a Further studies on the corticosteroidbinding globulin in the rat: proposed endocrine control. Endocrinology 79 67-76. (https://doi.org/10.1210/endo-79-1-67)

Gala RR \& Westphal U 1966b Influence of anterior pituitary hormones on the corticosteroid-binding globulin in the rat. Endocrinology 79 55-66. (https://doi.org/10.1210/endo-79-1-55)

Gatewood JD, Wills A, Shetty S, Xu J, Arnold AP, Burgoyne PS \& Rissman EF 2006 Sex chromosome complement and gonadal sex influence aggressive and parental behaviors in mice. Journal of Neuroscience 26 2335-2342. (https://doi.org/10.1523/ JNEUROSCI.3743-05.2006)

Gibbison B, Spiga F, Walker JJ, Russell GM, Stevenson K, Kershaw Y, Zhao Z, Henley D, Angelini GD \& Lightman SL 2015 Dynamic pituitary-adrenal interactions in response to cardiac surgery. Critical Care Medicine 43 791-800. (https://doi.org/10.1097/ CCM.0000000000000773)

Gjerstad JK, Lightman SL \& Spiga F 2018 Role of glucocorticoid negative feedback in the regulation of HPA axis pulsatility. Stress 21 403-416. (https://doi.org/10.1080/10253890.2018.1470238)

Goel N, Innala L \& Viau V 2014a Sex differences in serotonin (5-HT) $1 \mathrm{~A}$ receptor regulation of HPA axis and dorsal raphe responses to acute restraint. Psychoneuroendocrinology 40 232-241. (https://doi. org/10.1016/j.psyneuen.2013.11.020)

Goel N, Workman JL, Lee TT, Innala L \& Viau V 2014b Sex differences in the HPA axis. Comprehensive Physiology 4 1121-1155. (https://doi org/10.1002/cphy.c130054)

Gore AC, Martien KM, Gagnidze K \& Pfaff D 2014 Implications of prenatal steroid perturbations for neurodevelopment, behavior, and autism. Endocrine Reviews 35 961-991. (https://doi.org/10.1210/ er.2013-1122)

Hammond GL 2016 Plasma steroid-binding proteins: primary gatekeepers of steroid hormone action. Journal of Endocrinology 230 R13-R25. (https://doi.org/10.1530/JOE-16-0070)

Hammond GL, Smith CL, Goping IS, Underhill DA, Harley MJ, Reventos J, Musto NA, Gunsalus GL \& Bardin CW 1987 Primary structure of human corticosteroid binding globulin, deduced from hepatic and pulmonary cDNAs, exhibits homology with serine protease inhibitors. PNAS 84 5153-5157. (https://doi.org/10.1073/ pnas.84.15.5153)

Harris HJ, Kotelevtsev Y, Mullins JJ, Seckl JR \& Holmes MC 2001 Intracellular regeneration of glucocorticoids by 11beta-hydroxysteroid dehydrogenase (11beta-HSD)-1 plays a key role in regulation of the hypothalamic-pituitary-adrenal axis: analysis of 11beta-HSD-1deficient mice. Endocrinology 142 114-120. (https://doi.org/10.1210/ endo.142.1.7887)

Hartman ML, Veldhuis JD, Vance ML, Faria AC, Furlanetto RW \& Thorner MO 1990 Somatotropin pulse frequency and basal concentrations are increased in acromegaly and are reduced by successful therapy. Journal of Clinical Endocrinology and Metabolism 70 1375-1384. (https://doi.org/10.1210/jcem-70-5-1375)

Hazlehurst JM, Oprescu AI, Nikolaou N, Di Guida R, Grinbergs AEK, Davies NP, Flintham RB, Armstrong MJ, Taylor AE, Hughes BA, et al. 2016 Dual-5 $\alpha$-reductase inhibition promotes hepatic lipid accumulation in man. Journal of Clinical Endocrinology and Metabolism 101 103-113. (https://doi.org/10.1210/jc.2015-2928)

Henning SJ 1978 Plasma concentrations of total and free corticosterone during development in the rat. American Journal of Physiology 235 E451-E456. (https://doi.org/10.1152/ajpendo.1978.235.5.E451)

Herman JP, McKlveen JM, Ghosal S, Kopp B, Wulsin A, Makinson R, Scheimann J \& Myers B 2016 Regulation of the hypothalamic-pituita ry-adrenocortical stress response. Comprehensive Physiology 6 603-621. (https://doi.org/10.1002/cphy.c150015)

Holmes MC, Abrahamsen CT, French KL, Paterson JM, Mullins JJ \& Seckl JR 2006 The mother or the fetus? 11beta-Hydroxysteroid dehydrogenase type 2 null mice provide evidence for direct fetal programming of behavior by endogenous glucocorticoids. Journal of Neuroscience 26 3840-3844. (https://doi.org/10.1523/ JNEUROSCI.4464-05.2006)

Hundertmark S, Ragosch V, Schein B, Buhler H, Lorenz U, Fromm M \& Weitzel HK 1994 Gestational age dependence of 11 betahydroxysteroid dehydrogenase and its relationship to the enzymes of phosphatidylcholine synthesis in lung and liver of fetal rat. Biochimica et Biophysica Acta 1210 348-354. (https://doi. org/10.1016/0005-2760(94)90239-9)

Iannaccone PM \& Jacob HJ 2009 Rats! Disease Models and Mechanisms 2 206-210. (https://doi.org/10.1242/dmm.002733)

Jamieson PM, Nyirenda MJ, Walker BR, Chapman KE \& Seckl JR 1999 Interactions between oestradiol and glucocorticoid regulatory effects on liver-specific glucocorticoid-inducible genes: possible evidence for a role of hepatic 11beta-hydroxysteroid dehydrogenase type 1. Journal of Endocrinology 160 103-109. (https://doi.org/10.1677/ joe.0.1600103)

Jansson JO, Eden S \& Isaksson O 1985a Sexual dimorphism in the control of growth hormone secretion. Endocrine Reviews 6 128-150. (https:// doi.org/10.1210/edrv-6-2-128)

Jansson JO, Ekberg S, Isaksson O, Mode A \& Gustafsson JA 1985b Imprinting of growth hormone secretion, body growth, and hepatic steroid metabolism by neonatal testosterone. Endocrinology $\mathbf{1 1 7}$ 1881-1889. (https://doi.org/10.1210/endo-117-5-1881)

Jansson JO, Oscarsson J, Mode A \& Ritzen EM 1989 Plasma growth hormone pattern and androgens influence the levels of corticosteroidbinding globulin in rat serum. Journal of Endocrinology 122 725-732. (https://doi.org/10.1677/joe.0.1220725)

Jones JI \& Clemmons DR 1995 Insulin-like growth factors and their binding proteins: biological actions. Endocrine Reviews 16 3-34. (https://doi.org/10.1210/edrv-16-1-3)

Kadmiel M \& Cidlowski JA 2013 Glucocorticoid receptor signaling in health and disease. Trends in Pharmacological Sciences 34 518-530. (https://doi.org/10.1016/j.tips.2013.07.003)

Kamilaris TC, DeBold CR, Johnson EO, Mamalaki E, Listwak SJ, Calogero AE, Kalogeras KT, Gold PW \& Orth DN 1991 Effects of short and long duration hypothyroidism and hyperthyroidism on the plasma adrenocorticotropin and corticosterone responses to ovine corticotropin-releasing hormone in rats. Endocrinology 128 2567-2576. (https://doi.org/10.1210/endo-128-5-2567)

Keller-Wood M 2015 Hypothalamic-pituitary-adrenal axis-feedback control. Comprehensive Physiology 5 1161-1182. (https://doi. org/10.1002/cphy.c140065)

Kotelevtsev Y, Holmes MC, Burchell A, Houston PM, Schmoll D, Jamieson P, Best R, Brown R, Edwards CR, Seckl JR, et al. 1997 11beta-Hydroxysteroid dehydrogenase type 1 knockout mice show attenuated glucocorticoid-inducible responses and resist hyperglycemia on obesity or stress. PNAS 94 14924-14929. (https:// doi.org/10.1073/pnas.94.26.14924)

Kudielka BM, Buske-Kirschbaum A, Hellhammer DH \& Kirschbaum C 2004 HPA axis responses to laboratory psychosocial stress in healthy elderly adults, younger adults, and children: impact of age and gender. Psychoneuroendocrinology 29 83-98. (https://doi.org/10.1016/ s0306-4530(02)00146-4)

Lavery GG, Zielinska AE, Gathercole LL, Hughes B, Semjonous N, Guest P, Saqib K, Sherlock M, Reynolds G, Morgan SA, et al. 2012 Lack of significant metabolic abnormalities in mice with liver-specific disruption of $11 \beta$-hydroxysteroid dehydrogenase type 1. Endocrinology 153 3236-3248. (https://doi.org/10.1210/en.2012-1019)

Lax ER, Ghraf R \& Schriefers H 1978 The hormonal regulation of hepatic microsomal 11beta-hydroxysteroid dehydrogenase activity in the https://joe.bioscientifica.com

https://doi.org/10.1530/JOE-20-0286 (c) 2021 Society for Endocrinology Published by Bioscientifica Ltd. Printed in Great Britain 
rat. Acta Endocrinologica 89 352-358. (https://doi.org/10.1530/ acta.0.0890352)

Liu YJ, Nakagawa Y, Toya K \& Ozeki T 1997 Sex-specific effects of growth hormone on hepatic 11beta-hydroxysteroid dehydrogenase activity and gene expression in hypothyroid rats. Life Sciences 61 325-334. (https://doi.org/10.1016/s0024-3205(97)00389-5)

Livingstone DE, Di Rollo EM, Yang C, Codrington LE, Mathews JA, Kara M, Hughes KA, Kenyon CJ, Walker BR \& Andrew R 2014 Relative adrenal insufficiency in mice deficient in 5alpha-reductase 1. Journal of Endocrinology 222 257-266. (https://doi.org/10.1530/JOE-13-0563)

Loria P, Carulli L, Bertolotti M \& Lonardo A 2009 Endocrine and liver interaction: the role of endocrine pathways in NASH. Nature Reviews: Gastroenterology and Hepatology 6 236-247. (https://doi.org/10.1038/ nrgastro.2009.33)

Low SC, Chapman KE, Edwards CR, Wells T, Robinson IC \& Seckl JR 1994 Sexual dimorphism of hepatic 11 beta-hydroxysteroid dehydrogenase in the rat: the role of growth hormone patterns. Journal of Endocrinology 143 541-548. (https://doi.org/10.1677/joe.0.1430541)

Low MJ, Otero-Corchon V, Parlow AF, Ramirez JL, Kumar U, Patel YC \& Rubinstein M 2001 Somatostatin is required for masculinization of growth hormone-regulated hepatic gene expression but not of somatic growth. Journal of Clinical Investigation 107 1571-1580. (https://doi.org/10.1172/JCI11941)

Maniam J, Antoniadis C \& Morris MJ 2014 Early-life stress, HPA axis adaptation, and mechanisms contributing to later health outcomes. Frontiers in Endocrinology 5 73. (https://doi.org/10.3389/ fendo.2014.00073)

Masuzaki H \& Flier JS 2003 Tissue-specific glucocorticoid reactivating enzyme, 11 beta-hydroxysteroid dehydrogenase type 1 (11 betaHSD1) - a promising drug target for the treatment of metabolic syndrome. Current Drug Targets: Immune, Endocrine and Metabolic Disorders 3 255-262. (https://doi.org/10.2174/1568008033340135)

Mattos GE, Heinzmann JM, Norkowski S, Helbling JC, Minni AM, Moisan MP \& Touma C 2013 Corticosteroid-binding globulin contributes to the neuroendocrine phenotype of mice selected for extremes in stress reactivity. Journal of Endocrinology 219 217-229. (https://doi.org/10.1530/JOE-13-0255)

McCormick CM \& Mathews IZ 2010 Adolescent development, hypothalamic-pituitary-adrenal function, and programming of adult learning and memory. Progress in Neuro-Psychopharmacology and Biological Psychiatry 34 756-765. (https://doi.org/10.1016/j. pnpbp.2009.09.019)

McGowan PO \& Matthews SG 2018 Prenatal stress, glucocorticoids, and developmental programming of the stress response. Endocrinology 159 69-82. (https://doi.org/10.1210/en.2017-00896)

McNeilly AD, Macfarlane DP, O’Flaherty E, Livingstone DE, Mitic T, McConnell KM, McKenzie SM, Davies E, Reynolds RM, Thiesson HC, et al. 2010 Bile acids modulate glucocorticoid metabolism and the hypothalamic-pituitary-adrenal axis in obstructive jaundice. Journal of Hepatology 52 705-711. (https://doi.org/10.1016/j.jhep.2009.10.037)

Mendel CM 1989 The free hormone hypothesis: a physiologically based mathematical model. Endocrine Reviews 10 232-274. (https://doi. org/10.1210/edrv-10-3-232)

Meyer EJ, Nenke MA, Rankin W, Lewis JG \& Torpy DJ 2016 Corticosteroid-binding globulin: a review of basic and clinical advances. Hormone and Metabolic Research 48 359-371. (https://doi. org/10.1055/s-0042-108071)

Minni AM, de Medeiros GF, Helbling JC, Duittoz A, Marissal-Arvy N, Foury A, De Smedt-Peyrusse V, Pallet V \& Moisan MP 2014 Role of corticosteroid binding globulin in emotional reactivity sex differences in mice. Psychoneuroendocrinology 50 252-263. (https://doi. org/10.1016/j.psyneuen.2014.07.029)

Moore JS, Monson JP, Kaltsas G, Putignano P, Wood PJ, Sheppard MC Besser GM, Taylor NF \& Stewart PM 1999 Modulation of $11 \beta$-hydroxysteroid dehydrogenase Isozymes by growth hormone and insulin-like growth factor: in vivo and in vitro Studies1. Journa of Clinical Endocrinology and Metabolism 84 4172-4177. (https://doi org/10.1210/jcem.84.11.6108)

Morgan SA, McCabe EL, Gathercole LL, Hassan-Smith ZK, Larner DP, Bujalska IJ, Stewart PM, Tomlinson JW \& Lavery GG 2014 11betaHSD1 is the major regulator of the tissue-specific effects of circulating glucocorticoid excess. PNAS 111 E2482-E2491. (https://doi. org/10.1073/pnas.1323681111)

Murray HE, Simonian SX, Herbison AE \& Gillies GE 1999 Ontogeny and sexual differentiation of somatostatin biosynthesis and secretion in the hypothalamic periventricular-median eminence pathway. Journal of Neuroendocrinology 11 35-42. (https://doi.org/10.1046/j.13652826.1999.00287.x)

Myers B, McKlveen JM \& Herman JP 2014 Glucocorticoid actions on synapses, circuits, and behavior: implications for the energetics of stress. Frontiers in Neuroendocrinology 35 180-196. (https://doi. org/10.1016/j.yfrne.2013.12.003)

Nixon M, Upreti R \& Andrew R 2012 5alpha-Reduced glucocorticoids: a story of natural selection. Journal of Endocrinology 212 111-127. (https://doi.org/10.1530/JOE-11-0318)

Orava M, Zhao XF, Leiter E \& Hammond GL 1994 Structure and chromosomal location of the gene encoding mouse corticosteroidbinding globulin: strain differences in coding sequence and steroid-binding activity. Gene 144 259-264. (https://doi. org/10.1016/0378-1119(94)90387-5)

Ortiga-Carvalho TM, Chiamolera MI, Pazos-Moura CC \& Wondisford FE 2016 Hypothalamus-pituitary-thyroid axis. Comprehensive Physiology 6 1387-1428. (https://doi.org/10.1002/cphy.c150027)

Patel R, Williams-Dautovich J \& Cummins CL 2014 Minireview: new molecular mediators of glucocorticoid receptor activity in metabolic tissues. Molecular Endocrinology 28 999-1011. (https://doi. org/10.1210/me.2014-1062)

Paterson JM, Holmes MC, Kenyon CJ, Carter R, Mullins JJ \& Seckl JR 2007 Liver-selective transgene rescue of hypothalamic-pituitary-adrenal axis dysfunction in 11beta-hydroxysteroid dehydrogenase type 1-deficient mice. Endocrinology 148 961-966. (https://doi.org/10.1210/ en.2006-0603)

Perogamvros I, Ray DW \& Trainer PJ 2012 Regulation of cortisol bioavailability - effects on hormone measurement and action. Nature Reviews: Endocrinology 8 717-727. (https://doi.org/10.1038/ nrendo.2012.134)

Pignatelli D, Xiao F, Gouveia AM, Ferreira JG \& Vinson GP 2006 Adrenarche in the rat. Journal of Endocrinology 191 301-308. (https:// doi.org/10.1677/joe.1.06972)

Pryce CR 2008 Postnatal ontogeny of expression of the corticosteroid receptor genes in mammalian brains: inter-species and intraspecies differences. Brain Research Reviews 57 596-605. (https://doi. org/10.1016/j.brainresrev.2007.08.005)

Rabah SA, Gowan IL, Pagnin M, Osman N \& Richardson SJ 2019 Thyroid hormone distributor proteins during development in vertebrates. Frontiers in Endocrinology 10 506. (https://doi.org/10.3389/ fendo.2019.00506)

Refetoff S 2000 Thyroid hormone serum transport proteins. In Endotext [Internet], pp. 1-15. Eds Feingold KR, Anawalt B, Boyce A, Chrousos G, Dungan K, Grossman A, Hershman JM, Kaltsas G, Koch C, Kopp P, et al. South Dartmouth (MA): MDText.com, Inc.

Reul JM, Collins A, Saliba RS, Mifsud KR, Carter SD, Gutierrez-Mecinas M, Qian X \& Linthorst AC 2015 Glucocorticoids, epigenetic control and stress resilience. Neurobiology of Stress 1 44-59. (https://doi. org/10.1016/j.ynstr.2014.10.001)

Robinson PA, Langley MS \& Hammond GL 1985 A solid-phase radioimmunoassay for human corticosteroid binding globulin. Journal of Endocrinology 104 259-267. (https://doi.org/10.1677/ joe.0.1040259)

Russell G \& Lightman S 2019 The human stress response. Nature Reviews: Endocrinology 15 525-534. (https://doi.org/10.1038/s41574019-0228-0) https://joe.bioscientifica.com

https://doi.org/10.1530/JOE-20-0286 (c) 2021 Society for Endocrinology Published by Bioscientifica Ltd. Printed in Great Britain 
Sapolsky RM \& Meaney MJ 1986 Maturation of the adrenocortical stress response: neuroendocrine control mechanisms and the stress hyporesponsive period. Brain Research 396 64-76. (https://doi. org/10.1016/s0006-8993(86)80190-1)

Savu L, Vranckx R, Maya M \& Nunez EA 1987 A thyroxine binding globulin (TBG)-like protein in the sera of developing and adult rats. Biochemical and Biophysical Research Communications 148 1165-1173. (https://doi.org/10.1016/s0006-291x(87)80255-3)

Savu L, Vranckx R, Rouaze-Romet M, Maya M, Nunez EA, Tréton J \& Flink IL 1991 A senescence up-regulated protein: the rat thyroxinebinding globulin (TBG). Biochimica et Biophysica Acta 1097 19-22. (https://doi.org/10.1016/0925-4439(91)90017-4)

Savu L, Vranckx R, Rouaze-Romet M \& Nunez EA 1992 The pituitary control of rat thyroxine binding globulin. Acta Medica Austriaca 19 (Supplement 1) 88-90.

Schlechte JA \& Hamilton D 1987 The effect of glucocorticoids on corticosteroid binding globulin. Clinical Endocrinology 27 197-203. (https://doi.org/10.1111/j.1365-2265.1987.tb01145.x)

Seale JV, Wood SA, Atkinson HC, Bate E, Lightman SL, Ingram CD, Jessop DS \& Harbuz MS 2004 Gonadectomy reverses the sexually diergic patterns of circadian and stress-induced hypothalamicpituitary-adrenal axis activity in male and female rats. Journal of Neuroendocrinology 16 516-524. (https://doi.org/10.1111/j.13652826.2004.01195.x)

Seale JV, Wood SA, Atkinson HC, Lightman SL \& Harbuz MS 2005 Organizational role for testosterone and estrogen on adult hypothalamic-pituitary-adrenal axis activity in the male rat. Endocrinology 146 1973-1982. (https://doi.org/10.1210/en.2004-1201)

Sencar-Cupovic I \& Milkovic S 1976 The development of sex differences in the adrenal morphology and responsiveness in stress of rats from birth to the end of life. Mechanisms of Ageing and Development 5 1-9. (https://doi.org/10.1016/0047-6374(76)90002-6)

Shoba L, An MR, Frank SJ \& Lowe Jr WL 1999 Developmental regulation of insulin-like growth factor-I and growth hormone receptor gene expression. Molecular and Cellular Endocrinology 152 125-136. (https:// doi.org/10.1016/s0303-7207(99)00045-3)

Siiteri PK, Murai JT, Hammond GL, Nisker JA, Raymoure WJ \& Kuhn RW 1982 The serum transport of steroid hormones. Recent Progress in Hormone Research 38 457-510. (https://doi.org/10.1016/b978-0-12571138-8.50016-0)

Simonian SX, Murray HE, Gillies GE \& Herbison AE 1998 Estrogendependent ontogeny of sex differences in somatostatin neurons of the hypothalamic periventricular nucleus. Endocrinology 139 1420-1428. (https://doi.org/10.1210/endo.139.3.5814)

Smith CL \& Hammond GL 1991 Ontogeny of corticosteroid-binding globulin biosynthesis in the rat. Endocrinology 128 983-988. (https:// doi.org/10.1210/endo-128-2-983)

Spiga F \& Lightman SL 2015 Dynamics of adrenal glucocorticoid steroidogenesis in health and disease. Molecular and Cellular Endocrinology 408 227-234. (https://doi.org/10.1016/j. mce.2015.02.005)

Spiga F, Zavala E, Walker JJ, Zhao Z, Terry JR \& Lightman SL 2017 Dynamic responses of the adrenal steroidogenic regulatory network. PNAS 114 E6466-E6474. (https://doi.org/10.1073/pnas.1703779114)

Tannenbaum GS \& Martin JB 1976 Evidence for an endogenous ultradian rhythm governing growth hormone secretion in the rat. Endocrinology 98 562-570. (https://doi.org/10.1210/endo-98-3-562)

Thoeringer CK, Sillaber I, Roedel A, Erhardt A, Mueller MB, Ohl F, Holsboer F \& Keck ME 2007 The temporal dynamics of intrahippocampal corticosterone in response to stress-related stimuli with different emotional and physical load: an in vivo microdialysis study in C57BL/6 and DBA/2 inbred mice. Psychoneuroendocrinology 32 746-757. (https://doi.org/10.1016/j.psyneuen.2007.05.005)

Tinnikov AA 1999 Responses of serum corticosterone and corticosteroidbinding globulin to acute and prolonged stress in the rat. Endocrine 11 145-150. (https://doi.org/10.1385/ENDO:11:2:145)
Tohei A 2004 Studies on the functional relationship between thyroid, adrenal and gonadal hormones. Journal of Reproduction and Development 50 9-20. (https://doi.org/10.1262/jrd.50.9)

Torres JM \& Ortega E 2004 Precise quantitation of steroid 5alpha lambda pi eta alpha-reductase type $1 \mathrm{mRNA}$ levels by RT-PCR in female rat liver. Endocrine Research 30 149-157. (https://doi.org/10.1081/erc-200027371)

Tschöp M, Lahner H, Feldmeier H, Grasberger H, Morrison KM, Janssen OE, Attanasio AF \& Strasburger CJ 2000 Effects of growth hormone replacement therapy on levels of cortisol and cortisolbinding globulin in hypopituitary adults. European Journal of Endocrinology 143 769-773. (https://doi.org/10.1530/eje.0.1430769)

Van Baelen H, Adam-Heylen M, Vandoren G \& De Moor P 1977 Neonatal imprinting of serum transcortin levels in the rat. Journal of Steroid Biochemistry 8 735-736. (https://doi.org/10.1016/0022-4731(77)90005-x)

Verbeeten KC \& Ahmet AH 2018 The role of corticosteroid-binding globulin in the evaluation of adrenal insufficiency. Journal of Pediatric Endocrinology and Metabolism 31 107-115. (https://doi.org/10.1515/ jpem-2017-0270)

Viau V 2002 Functional cross-talk between the hypothalamic-pituitarygonadal and -adrenal axes. Journal of Neuroendocrinology 14 506-513. (https://doi.org/10.1046/j.1365-2826.2002.00798.x)

Viau V \& Meaney MJ 2004 Testosterone-dependent variations in plasma and intrapituitary corticosteroid binding globulin and stress hypothalamic-pituitary-adrenal activity in the male rat. Journal of Endocrinology 181 223-231. (https://doi.org/10.1677/joe.0.1810223)

Viau V, Sharma S \& Meaney MJ 1996 Changes in plasma adrenocorticotropin, corticosterone, corticosteroid-binding globulin, and hippocampal glucocorticoid receptor occupancy/translocation in rat pups in response to stress. Journal of Neuroendocrinology 8 1-8. (https://doi.org/10.1111/j.1365-2826.1996.tb00680.x)

Vranckx R, Savu L, Maya M \& Nunez EA 1990a Characterization of a major development-regulated serum thyroxine-binding globulin in the euthyroid mouse. Biochemical Journal 271 373-379. (https://doi. org/10.1042/bj2710373)

Vranckx R, Rouaze M, Savu L, Nunez EA, Beaumont C \& Flink IL $1990 b$ The hepatic biosynthesis of rat thyroxine binding globulin (TBG): demonstration, ontogenesis, and UP-regulation in experimental hypothyroidism. Biochemical and Biophysical Research Communications 167 317-322. (https://doi.org/10.1016/0006$291 x(90) 91767-m)$

Wagner C, Caplan SR \& Tannenbaum GS 1998 Genesis of the ultradian rhythm of GH secretion: a new model unifying experimental observations in rats. American Journal of Physiology 275 E1046-E1054. (https://doi.org/10.1152/ajpendo.1998.275.6.E1046)

Walker BR \& Andrew R 2006 Tissue production of cortisol by 11betahydroxysteroid dehydrogenase type 1 and metabolic disease. Annals of the New York Academy of Sciences 1083 165-184. (https://doi. org/10.1196/annals.1367.012)

Walker P, Dubois JD \& Dussault JH 1980 Free thyroid hormone concentrations during postnatal development in the rat. Pediatric Research 14 247-249. (https://doi.org/10.1203/00006450-19800300000014)

Waner T \& Nyska A 1988 Thyroxine (T4) and triiodothyronine (T3) levels in the Fischer 344 inbred rat. Laboratory Animals 22 276-280. (https:// doi.org/10.1258/002367788780746458)

Welberg LA, Seckl JR \& Holmes MC 2000 Inhibition of 11betahydroxysteroid dehydrogenase, the foeto-placental barrier to maternal glucocorticoids, permanently programs amygdala GR mRNA expression and anxiety-like behaviour in the offspring. European Journal of Neuroscience 12 1047-1054. (https://doi.org/10.1046/j.14609568.2000.00958.x)

Whirledge S \& Cidlowski JA 2013 A role for glucocorticoids in stressimpaired reproduction: beyond the hypothalamus and pituitary. Endocrinology 154 4450-4468. (https://doi.org/10.1210/en.2013-1652)

Windle RJ, Wood SA, Shanks N, Lightman SL \& Ingram CD 1998 Ultradian rhythm of basal corticosterone release in the female rat: https://joe.bioscientifica.com https://doi.org/10.1530/JOE-20-0286 (c) 2021 Society for Endocrinology Published by Bioscientifica Ltd. Printed in Great Britain 
dynamic interaction with the response to acute stress. Endocrinology 139 443-450. (https://doi.org/10.1210/endo.139.2.5721)

Woeber KA \& Ingbar SH 1968 The contribution of thyroxine-binding prealbumin to the binding of thyroxine in human serum, as assessed by immunoadsorption. Journal of Clinical Investigation 47 1710-1721. (https://doi.org/10.1172/JCI105861)

Yau JL, Noble J, Kenyon CJ, Ludwig M \& Seckl JR 2015 Diurnal and stress-induced intra-hippocampal corticosterone rise attenuated in 11beta-HSD1-deficient mice: a microdialysis study in young and aged mice. European Journal of Neuroscience 41 787-792. (https://doi. org/10.1111/ejn.12836)
Yoshimura S, Sakamoto S, Kudo H, Sassa S, Kumai A \& Okamoto R 2003 Sex-differences in adrenocortical responsiveness during development in rats. Steroids 68 439-445. (https://doi.org/10.1016/s0039$128 \mathrm{x}(03) 00045-\mathrm{x})$

Yu Y, Fuscoe JC, Zhao C, Guo C, Jia M, Qing T, Bannon DI, Lancashire L, Bao W, Du T, et al. 2014 A rat RNA-Seq transcriptomic BodyMap across 11 organs and 4 developmental stages. Nature Communications 5 3230. (https://doi.org/10.1038/ncomms4230)

Zoeller RT, Tan SW \& Tyl RW 2007 General background on the hypothalamic-pituitary-thyroid (HPT) axis. Critical Reviews in Toxicology 37 11-53. (https://doi.org/10.1080/10408440601123446)

Received in final form 29 September 2020

Accepted 20 October 2020

Accepted Manuscript published online 20 October 2020 (c) 2021 Society for Endocrinology Published by Bioscientifica Ltd.
Printed in Great Britain 